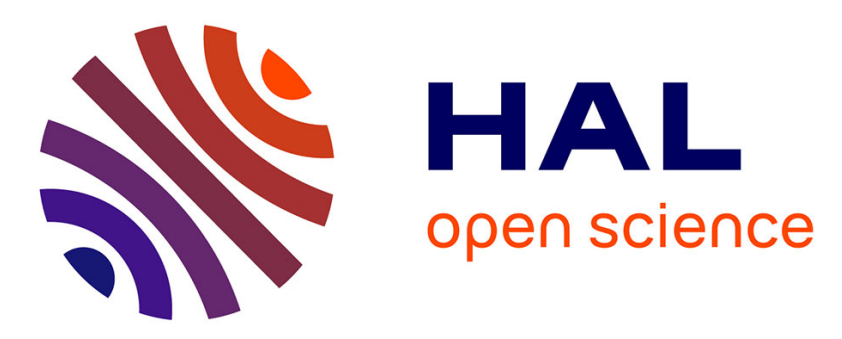

\title{
Multi-scale structural changes of starch and proteins during pea flour extrusion
}

\author{
Magdalena Kristiawan, Valerie Micard, Priscilla Maladira, Christine \\ Alchamieh, Jean-Eudes Maigret, Anne-Laure Réguerre, M.A. Emin, Guy \\ Della Valle
}

\section{To cite this version:}

Magdalena Kristiawan, Valerie Micard, Priscilla Maladira, Christine Alchamieh, Jean-Eudes Maigret, et al.. Multi-scale structural changes of starch and proteins during pea flour extrusion. Food Research International, 2018, 108, pp.203-215. 10.1016/j.foodres.2018.03.027 . hal-01837510

\section{HAL Id: hal-01837510 https://hal.science/hal-01837510}

Submitted on 26 May 2020

HAL is a multi-disciplinary open access archive for the deposit and dissemination of scientific research documents, whether they are published or not. The documents may come from teaching and research institutions in France or abroad, or from public or private research centers.
L'archive ouverte pluridisciplinaire HAL, est destinée au dépôt et à la diffusion de documents scientifiques de niveau recherche, publiés ou non, émanant des établissements d'enseignement et de recherche français ou étrangers, des laboratoires publics ou privés.

\section{(c)(1)}

Distributed under a Creative Commons Attribution| 4.0 International License 


\section{Accepted Manuscript}

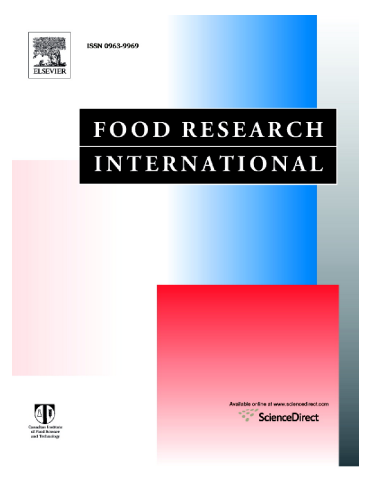

M. Kristiawan, V. Micard, P. Maladira, C. Alchamieh, J.-E.

Maigret, A.-L. Réguerre, M.A. Emin, G. Della Valle

PII:

S0963-9969(18)30203-5

DOI: doi:10.1016/j.foodres.2018.03.027

Reference:

FRIN 7464

To appear in:

Food Research International

Received date:

5 January 2018

Revised date:

7 March 2018

Accepted date:

9 March 2018

Please cite this article as: M. Kristiawan, V. Micard, P. Maladira, C. Alchamieh, J.-E. Maigret, A.-L. Réguerre, M.A. Emin, G. Della Valle , Multi-scale structural changes of starch and proteins during pea flour extrusion. The address for the corresponding author was captured as affiliation for all authors. Please check if appropriate. Frin(2018), doi:10.1016/j.foodres.2018.03.027

This is a PDF file of an unedited manuscript that has been accepted for publication. As a service to our customers we are providing this early version of the manuscript. The manuscript will undergo copyediting, typesetting, and review of the resulting proof before it is published in its final form. Please note that during the production process errors may be discovered which could affect the content, and all legal disclaimers that apply to the journal pertain. 
Multi-s cale structural changes of starch and proteins during pea flour extrusion

${ }^{1} *$ M. Kristiawan, ${ }^{2}$ V. Micard, ${ }^{1,2}$ P. Maladira, ${ }^{1}$ C. Alchamieh, ${ }^{1}$ J.-E. Maigret, ${ }^{1}$ A.-L. Réguerre, ${ }^{3}$ M.A. Emin, and ${ }^{1}$ G. Della Valle

${ }^{1}$ INRA, UR 1268 Biopolymers Interactions and Assemblies (BIA), 44316 Nantes, France ${ }^{2}$ Montpellier SupAgro-INRA-UM-CIRAD, JRU IATE 1208, 34060 Montpellier, France

${ }^{3}$ Karlsruhe Institute of Technology, Institute of Process Engineering in Life Sciences, 76131 Karlsruhe, Germany

*Corresponding author: magdalena.kristiawan@inra.fr 


\section{Abstract}

Dehulled yellow pea flour (48.2\% starch, $23.4 \%$ proteins, d.b.), was processed by a twinscrew extruder at various moisture contents $M C$ (18-35\% w.b.), product temperature $T\left(115-165^{\circ} \mathrm{C}\right)$, and specific mechanical energy SME (50-1200 kJ/kg). Structural changes of extruded pea flour were determined at different scales by measurements of density (expansion), crystallinity (X-ray diffraction), gelatinisation enthalpy (DSC), starch solubility in water and protein solubility in SDS and DTE (SE-HPLC). Foam density dropped from 820 to $85 \mathrm{~kg} / \mathrm{m}^{3}$ with increase in $S M E$ and $T\left(\mathrm{R}^{2} \geq 0.78\right)$. DSC and XRD results showed that starch was amorphous whatever extrusion conditions. Its solubility in water augmented up to $50 \%$. Increasing temperature from 115 to $165^{\circ} \mathrm{C}$ decreased proteins soluble in SDS from 95 to $35 \%\left(\mathrm{R}^{2}=0.83\right)$ of total proteins, whereas the proteins soluble in DTE increased from 5 to $45 \%\left(R^{2}=0.75\right)$ of total proteins. These trends could be described by sigmoid models, which allowed determining onset temperatures for changes of protein solubility in the interval $\left[125,146^{\circ} \mathrm{C}\right]$, whatever moisture content. The SME impact on protein solubility followed similar trends. These results suggest the creation of protein network by S-S bonds, implicating larger SDS-insoluble protein aggregates, as a result of increasing $T$ and $S M E$, accompanied by creation of covalent bonds other than S-S ones. CSLM images suggested that extruded pea flour had a composite morphology that changed from dispersed small protein aggregates to a bi-continuous matrix of large protein aggregates and amorphous starch. This morphology would govern the expansion of pea flour by extrusion.

\section{Keywords}

Composite morphology, expansion, protein aggregates, solid foam, solubility

\section{Abbre viations and nomenclature}

$\begin{array}{ll}a, b, b_{1}, b_{2}, k, m, T_{c} & \text { parameters in fitting equations } \\ a^{*} & \text { one of three coordinates of CIE color space which represents redness } \\ b^{*} & \text { one of three coordinates of CIE color space which represents yellowness } \\ \text { CSLM } & \text { confocal laser scanning microscopy } \\ \text { d.b. } & \text { dry basis } \\ \text { DTE } & \text { dithioerythritol } \\ \text { DSC } & \text { differential scanning calorimetry } \\ \text { GMO } & \text { genetically-modified organism } \\ L^{*} & \text { one of three coordinates of CIE color space which represents lightness } \\ L E I & \text { longitudinal expansion index } \\ \Delta H_{u} & \text { melting enthalpy per mole of monomer unit (or anhydroglucose) (in } \mathrm{kJ} / \mathrm{mol} \text { ) } \\ M C & \text { moisture content, in wet basis } \\ M_{W} & \text { molecular weight }\end{array}$


screw speed (rpm)

$N_{\max }$

$p$

$P_{\max }$

PPA

$Q$

$Q_{F}$

$Q_{W}$

$R$

$S_{i}$

SDS

SE-HPLC

SEI

Sol.

SME

$T$

$T_{\text {die }}$

$T_{i}$

$T_{m}$

$T_{m}^{\circ}$

$v_{1}$

$V_{u}$

$V_{l}$

VEI

WAXS

WAI

w.b.

WSI

WSI $I_{\text {solids }}$

WSI $I_{\text {starch }}$

XRD

$\varnothing$

$\rho^{*}$

$2 \theta$

$\tau$

$\tau_{\text {empty }}$

$\chi_{1}$

maximum screw speed (rpm)

significance level

maximum power $(\mathrm{kJ})$

Acriflavine-Schiff reagent for starch staining

total mass flow rate $(\mathrm{kg} / \mathrm{h})$

mass flow rate of pea flour $(\mathrm{kg} / \mathrm{h})$

mass flow rate of water $(\mathrm{kg} / \mathrm{h})$

gas constant $\left(8.31 \times 10^{-3} \mathrm{~kJ} / \mathrm{mol} . \mathrm{K}\right)$

SDS-soluble proteins fractions (\%) with $i$ represents $i^{\text {th }}$ fractions

sodium dodecyl sulphate

size-exclusion high-performance liquid chromatography

sectional expansion index

protein solubility

specific mechanical energy $(\mathrm{kJ} / \mathrm{kg})$

product temperature $\left({ }^{\circ} \mathrm{C}\right)$, measured at the end of extruder

imposed die temperature $\left({ }^{\circ} \mathrm{C}\right)$

temperature at the onset of starch and protein changes $\left({ }^{\circ} \mathrm{C}\right)$

melting temperature of $\operatorname{starch}\left({ }^{\circ} \mathrm{C}\right)$

melting temperature of anhydrous starch (in K)

water volume fraction (dimensionless)

molar volume of the monomer unit (dimensionless)

molar volume of water (dimensionless)

volumetric expansion index

wide angle $\mathrm{X}$-ray scattering

water absorption index (in \% dry powder)

wet basis

water solubility index

WSI of total solids (in $\mathrm{kg} / \mathrm{kg}$ dry flour)

WSI of starch (in $\mathrm{kg} / \mathrm{kg}$ dry starch in flour)

$\mathrm{X}$-ray diffraction

diameter

density of extrudates $\left(\mathrm{kg} / \mathrm{m}^{3}\right)$

scattering angle $\left(^{\circ}\right)$

measured torque (in $\%$ of maximum torque)

measured torque when extruder is empty (in \% of maximum torque)

Flory-Huggins starch-water interaction parameter (dimensionless) 


\section{Introduction}

Pulse legumes (pea, lentil, faba bean) are excellent source of proteins (20-30\% dry basis), dietary fibers (10-30\%), starch (40-55\%), vitamins and minerals, and they are low in sugar, sodium and fat (El-Adawy, Rahma, El-Bedawey, \& El-Beltagy, 2003). Pulse proteins are relatively high in lysine and low in sulphur-containing amino acids: cysteine, methionine, and tryptophan (Leterme, Monmart, \& Baudart, 1990). Combination of pulse proteins with low-lysine cereal proteins allows a nutritional adequate protein profile. The formulation of gluten-free extruded snacks made entirely from pulse legumes is also an interesting way to introduce pulse to modern consumers demanding vegan, gluten free, non-GMO and protein enriched functional foods.

Extrusion is one of the most versatile and efficient food processing technique used in preparation of starch based foods and especially to process protein-fortified extrudates (Day \& Swanson, 2013). After melting, the viscous material is forced through a die where the vapour expands the material to a porous structure. Texture properties of extruded products, envisioned like solid foam, depend not only on density and cellular structure but also on the mechanical properties of the material which constitutes the cell walls of the foam. These properties depend on the morphology of the cell wall material created during extrusion under high temperature and shear. These conditions lead to many biopolymer transformations: starch melting, depolymerisation, protein denaturation, browning, and destruction of anti-nutritional components. With increasing temperature, molecular changes in proteins take place in several steps: association, dissociation, and aggregation of subunits by noncovalent (hydrophobic, ionic, H) and covalent (disulphide, isopeptide) bonds (Stanley, 1989). In the case of extrusion of soy and pea protein isolates, the increasing shear energy promotes protein unfolding resulting in protein re-association (Della Valle, Quillien, \& Gueguen, 1994; Fang, Zhang, Wei, \& Li, 2013). Besides, moisture content probably increases the mobility of proteins and their cross-linking (Holay \& Harper, 1982).

The knowledge about the bonding forces involved in protein changes during extrusion was generally deducted from experiments on protein solubility of extrudates in selective reagents capable to disrupt specific bonds. Most of the studies on legume protein solubility have focused on high moisture extrusion ( $>50 \%$ w.b.) producing meat analogues from soy and pea protein isolates. Recent studies show that the meat analogue structuring is more related to thermodynamic incompatibility, which could be induced by protein-protein interactions (Tolstoguzov, 2016).

Most studies on expanded snacks, made from legume proteins extruded at lower moisture ( $\leq 25 \%$ w.b.), focused mainly on the effect of extrusion variables on density, expansion and functional properties using black box modelling for optimizing. Studies on the changes of protein structure and solubility were performed after extrusion, generally in a narrow extrusion domain, and did not involve macroscopic features like expansion (Alonso, Orue, Zabalza, Grant, \& Marzo, 2000; Ben-Hdech, 
Gallant, Bouchet, Gueguen, \& Melcion, 1991; Della Valle et al., 1994; Gujska \& Khan, 1991). More recently, protein aggregations have been studied on pulse legume based pasta extruded at moisture content between 30 and 35\% (w.b.) and low temperature $\left(<100^{\circ} \mathrm{C}\right)$ (Laleg et al., 2017). However pasta are not expanded product. The diversity of protein sources and processing conditions make the comparison of results difficult and sometimes contradictory. Published results about the effect of protein content on sectional expansion index (SEI) showed both negative and positive impact. Paton \& Spratt (1984) found that for extrusion of gluten-wheat starch blend (moisture content $M C 21 \%, 163^{\circ} \mathrm{C}$, $50 \mathrm{rpm}$ ), the $S E I$ increased from 3 to 5 when adding $10 \%$ gluten. Conversely, for extrusion held at the same level of $M C$ but higher mechanical energy (230 rpm), De Mesa et al. (2009) found that an addition of 5-20\% soy protein concentrate into corn starch decreased SEI from 17 to 7 . The increase of protein content from 6 to18\% during extrusion of pea flour $\left(M C 21 \%, 120^{\circ} \mathrm{C}\right)$ resulted in $S E I$ drop from 7 to 2 (Hood-Niefer and Tyler, 2010). The effects of extrusion variables on mechanism of protein transformations and, consequently, on multi-scale structure of legume based starch-protein matrices are still not well understood. Depending on operating variables of extrusion, destructured starches and insoluble protein aggregates can form a melt with various morphologies. In turn, the morphology affects expansion and functional properties (i.e. foam texture) through the change of melt rheology.

The first objective of this work is to ascertain the effect of biopolymer transitions on the structure of extruded pea flour. The structure was studied at two levels: (1) the cell walls of foams constituted by starch-protein blends, and (2) the overall expansion. Second objective is to determine the relationship between extrusion variables, product structure, and material transformations on a mechanistic basis. A wide range of extrusion conditions was selected and resulting products were thoroughly analysed at different levels of matter organization.

\section{Materials and methods}

\subsection{Raw materials}

Dehulled yellow split pea grits was obtained from Sotexpro (France). The pea (variety Karpate) was harvested in spring 2016. The pea grits were ground by a miller (Sarl Giraud, France) in order to obtain pea flour with median diameter of about $480 \mu \mathrm{m}$.

\subsubsection{Chemical composition (in dry basis)}

Total crude protein content of pea flour was obtained using Kjeldahl procedure with a nitrogen-to-protein conversion factor of 6.25. Total starch content was determined with an enzymatic assay kit (Megazyme, Co., Ireland). Ash content was determined by incineration at $900{ }^{\circ} \mathrm{C}$ for $2 \mathrm{~h}$ according to the French standard (NF 03-720). Total lipids were extracted according to method of Folch et al. (1957). All measurements were conducted in triplicate. The reported values are averages 
with relative standard deviation lower than $5 \%$. Fibre content was calculated by subtraction of average content (\% d.b.) of ash, fat, protein and starch from total chemical content.

\subsection{Extrusion trials}

Pea flour was extruded using a laboratory scale co-rotating twin-screw extruder (Coperion Werner \& Pfleiderer ZSK 26Mc). The screw diameter was $25.5 \mathrm{~mm}$. The barrel was divided into 7 sections with a total length of $740 \mathrm{~mm}$. During the experiments, each barrel section, except the first one, was heated separately to $40,60,80,90,90$, and $90^{\circ} \mathrm{C}$. The raw material was fed by a gravimetrically controlled feeder (Brabender DDW-DDSR 40). Water was added into the second barrel by a volumetric pump. The screw profile included (i) conveying elements with decreasing pitch from 36 to $24 \mathrm{~mm}$, (ii) followed by three $45^{\circ}$ kneading discs (length of $12 \mathrm{~mm}$ each) located inside the fourth barrel, (iii) three reverse elements having pitch and length of $12 \mathrm{~mm}$ located inside the fifth barrel, (iv) conveying elements having pitch of $24 \mathrm{~mm}$. This geometry assured (i) homogeneous mixing of flour and water at the inlet (ii) melting dough completely in the stagnant area generated by reverse elements and (iii) conveying the molten phase to die.

In order to obtain extrudates having a wide range of structures and biopolymer transformations,a large domain of operating parameters was applied: moisture content $18-35 \%$ w.b., screw speed 300-700 rpm, total feed rate 10-25 kg/h, extruder configuration with (A) and without (B) restrictive elements, and imposed die temperature $130-150^{\circ} \mathrm{C}$. Two die geometries were used: die $\mathrm{C}$ consisted of a long slit die (thickness $3 \mathrm{~mm}$, width $15 \mathrm{~mm}$, length $72 \mathrm{~mm}$ ) followed by an orifice die ( $\varnothing$ $3 \mathrm{~mm}$, length $15 \mathrm{~mm}$ ), die D consisted of an orifice die mounted directly to the extruder head without slit die. Extrusion parameters are summarized in Table 1. The interval of variations of these parameters was chosen by numerical screening using a twin-screw simulation software Ludovic ${ }^{\circledR}$ (Vergnes, Della Valle, \& Delamare, 1998), in order to cover a wide range of extrusion variables, such as product temperature $115-165^{\circ} \mathrm{C}$ and specific mechanical energy $(S M E) 40-1200 \mathrm{~kJ} / \mathrm{kg}$. In addition, the knowledge of pea starch melting temperature at various moisture contents was used for setting extrusion conditions to obtain extrudates with amorphous starch mainly under low $S M E(<100 \mathrm{~kJ} / \mathrm{kg})$ (Logié, Della Valle, Rolland-Sabaté, Descamps, \& Soulestin, 2018).

In particular, experiments using relatively high moisture content (between 26 and 35\%) were performed to produce dense material samples (low expansion) that can be considered as the constitutive material ("parietal material") of the pea flour foams (expanded samples). Die pressure and product temperature were measured just in the last section of the extruder with an accuracy of $\pm 0.25 \%$ and $\pm 0.5^{\circ} \mathrm{C}$, respectively. Specific mechanical energy $(S M E, \mathrm{~kJ} / \mathrm{kg})$ was calculated from screw speed, measured torque and power as follows:

$$
S M E=\frac{\frac{N}{N_{\max }} \times \frac{\tau-\tau_{\text {empty }}}{100}}{Q} \times P_{\max } \times 3600
$$


where $N$ and $N_{\max }$ are the actual and maximum screw speed $\left(N_{\max }=1800 \mathrm{rpm}\right), \tau$ and $\tau_{\text {empty }}$ are the actual and empty measured torque. The maximum power of extruder $P_{\max }$ is $40 \mathrm{~kW}$. $Q$ is the total mass flow rate $(\mathrm{kg} / \mathrm{h})$.

The extrudates were dried under vacuum at $40^{\circ} \mathrm{C}$ overnight in order to get final moisture content less than $10 \%$ w.b. and stored in airtight plastic bags at room temperature. A part of each extrudate was ground into a fine powder using a grinder (M20, IKA Werke GmbH \& Co., Germany). The ground samples and pea flour were sieved to pass a $250 \mu \mathrm{m}$ mesh and conditioned at a relative humidity of $59 \%$ at $20^{\circ} \mathrm{C}$ for two weeks.

\subsection{Product analysis}

\subsubsection{Density and sectional expansion index}

Extrudate density reflects overall or volumetric expansion expressed by the index $V E I \approx$ melt density / extrudate density. Volumetric expansion results from radial and longitudinal expansions, each term being assessed by a specific index (Kristiawan, Chaunier, Della Valle, Ndiaye, \& Vergnes, 2016). Longitudinal expansion index ( $L E I)$ characterizes the expansion in die flow direction, whereas radial or sectional expansion index $(S E I)$ refers to the increase of cross section in the plane orthogonal to flow direction. The three indices are linked by the relationship:

$$
V E I=L E I \times S E I
$$

In this work, macro structure of extrudates was characterized by density and SEI. The bulk density was obtained using glass beads displacement method. The extrudate density $\left(\rho^{*}\right)$ was calculated from the mass of extrudate and its volume measured through the displacement of glass beads $(\varnothing 1 \mathrm{~mm})$. The reported values (Table 2) were the averages of three repetitions (relative error $10 \%)$. The SEI was calculated as the ratio of cross-sectional area of extrudate to that of die. For each sample, diameter was measured at five random positions on each of seven pieces of extrudates. The reported $S E I$ values were the averages of these thirty-five measurements (relative error $15 \%$ ).

\subsubsection{Starch transformation}

\section{Melting transition}

Pea flours with various moisture contents ( 5 to $35 \%$ wet basis) were prepared under controlled relative humidity of 11 to $97 \%$ over saturated salts at $20^{\circ} \mathrm{C}$ for $1-2$ weeks. DSC Q10 (TA Instrument, France) was used for melting point analysis following the method of Barron et al. (2000). The samples were heated from 25 to $180^{\circ} \mathrm{C}$ at a heating rate of $3^{\circ} \mathrm{C} / \mathrm{min}$. Melting temperature $\left(T_{m}\right)$ was defined as the offset temperature of endothermic peak. The measurements were done in duplicate (relative error $10 \%)$. 
The degree of starch transformation (crystallinity loss and granular disorganization) was determined by duplicate measurements of DSC gelatinization enthalpy of extrudates, in excess water, compared to untreated pea flour. Absence of residual gelatinization enthalpy means that starch is amorphous. The DSC scans were run at $3^{\circ} \mathrm{C} / \mathrm{min}$ from 10 to $120^{\circ} \mathrm{C}$.

\section{Crystallinity state by WAXS}

The loss of crystallinity was also examined using a wide angle $\mathrm{x}$-ray scattering analysis (WAXS) (Barron et al., 2000). The analysis was performed using a Bruker D8 diffractometer (Bruker AXS Inc., USA) equipped with a copper source operating at $40 \mathrm{kV}$ and $40 \mathrm{~mA}$.

\section{Water Solubility Index (WSI) and Water Absorption Index (WAI)}

Water solubility index of total solids ( $W S I_{\text {solids }}$ ) and water absorption index (WAI) of flour and ground extrudates were determined using the method of Anderson et al. (1970). Mass of $2.5 \mathrm{~g}$ of samples was dispersed in $30 \mathrm{ml}$ of distilled water, then agitated at $30^{\circ} \mathrm{C}$ for $30 \mathrm{~min}$ and finally centrifuged at $3000 \mathrm{~g}$ for $10 \mathrm{~min}$ at $20^{\circ} \mathrm{C}$. The supernatant was dried overnight in a Chopin oven at $105^{\circ} \mathrm{C}$. WAI was calculated as the ratio of mass of wet pellet to dry original sample. WSI $I_{\text {solids }}$ was determined as the percentage of mass of supernatant dry solid to dry original sample.

For determining WSI of starch (WSI starch $)$, the samples underwent firstly the same extraction and centrifugation procedure as described before. Thereafter, the supernatant was titrated with orcinol in an automatic spectrocolorimeter, according to the method of Tollier and Robin (1979).

The measurements of WSI and WAI were carried out in triplicate (relative error 15\%).

\subsubsection{Protein transformation}

\section{Procedure of protein extraction}

Proteins were extracted using a method adapted from Morel et al. (2000). Samples underwent two successive extractions. The first stage, aiming to extract SDS-soluble proteins, was conducted at $60^{\circ} \mathrm{C}$ for 80 min with a sodium phosphate buffer containing $1 \%$ of sodium dodecyl sulphate (SDS, 0.1 M) with a solid-to-solvent ratio of $8 \mathrm{mg} / \mathrm{mL}$. SDS disrupts the electrostatic, hydrophobic and hydrophilic interactions between proteins. After centrifugation, $1 \mathrm{~mL}$ of the supernatant was analysed on size distribution using SE-HPLC. During the second extraction, the pellet was suspended in a $5 \mathrm{~mL}$ of the SDS-phosphate buffer containing $20 \mathrm{mM}$ of dithioerythritol (DTE) at $60^{\circ} \mathrm{C}$ for $60 \mathrm{~min}$, sonicated for $5 \mathrm{~min}$ and centrifuged. The supernatant, referred as DTE-soluble proteins, was sampled for SE-HPLC analysis. The combination of sonication and DTE causes disruption of disulphide bonds. The remaining pellet made of non-extractable proteins represents proteins linked by other covalent bonds than S-S ones (e.g. isopeptides bonds). Protein solubility (\%) in a specified reagent (SDS or DTE) is expressed as the percentage of integrated area to that of all extractable proteins of a 
reference sample D8. As explained in detail later, D8 has been chosen because it has maximum total extractable proteins.

\section{Measurement of molecular weight distribution of proteins aggregates}

The size distribution of protein aggregates in the extracts was studied by Size-Exclusion HighPerformance Liquid Chromatography (SE-HPLC). The SE-HPLC apparatus (Waters LC Module1 plus) was equipped with an analytical column TSK G4000-SW, 7.5 x $300 \mathrm{~mm}$ (Merck, France) and a guard column TSK G3000-SW, 7.5 x 75 mm (Merck, France). Apparent molecular weights were determined in the column calibrated with protein standards (Redl, Morel, Bonicel, Vergnes, \& Guilbert, 1999). Once corrected for their different solid-to-solvent ratios, the integrated areas of SDSsoluble and DTE-soluble proteins of samples were expressed as percentage of the total area of the reference sample D8 giving the maximum total extractable proteins. The solubility experiments were duplicated (relative error 5\%).

\subsubsection{Colormeasurement}

Color changes of ground samples (sieved between 250 and $500 \mu \mathrm{m}$ ) were assessed by measurement of CIE Lab color space ( $L^{*}, a^{*}$ and $\left.b^{*}\right)$ using a chromameter (Konica Minolta CR-400) with a standard illuminant D65 (natural daylight), and an observation angle of $2^{\circ}$. $L^{*}$ stands for lightness black-white $(0,100), a^{*}$ and $b^{*}$ for color opponents green-red $(-100,+100)$ and blue-yellow $(-100,+100)$, respectively. Color measurements were done in triplicate (relative error $1 \%)$. These color changes could reflect Maillard reactions occurring between reducing sugars and free amine groups due to thermo-mechanical treatment.

\subsubsection{Morphology of starch-protein blends}

Confocal laser scanning microscopy (CLSM) was used to locate the starch/protein phases in the constitutive material of extruded samples. The extrudates were cut perpendicularly and embedded in paraffin using a method adapted from Ben Hdech et al. (1991). The slices of $10 \mu \mathrm{m}$ were then cut using a rotary microtome. Starch was stained red with oxidation in periodic acid solution followed by coloration with Acriflavine-Schiff reagent, called as PAA staining. Proteins were stained green with $0.01 \%(\mathrm{w} / \mathrm{v})$ Fuchsine Acid in 1\% (v/v) acetic acid (Chanvrier, Colonna, Della Valle, \& Lourdin, 2005). Images were acquired using a confocal laser scanning microscope (Nikon A1) with attached NIS imaging system (Nikon, Germany). Samples were examined in the epifluorescence mode of the microscope, excited by a green laser beam at $561 \mathrm{~nm}$ for Fuchsine Acid stain and at $488 \mathrm{~nm}$ for PAA stain. The emitted light was selected by a long-pass filter $(>570 \mathrm{~nm})$. Three-dimensional images of samples were obtained by observing 20 planes of $1 \mu \mathrm{m}$ thick, every $1 \mu \mathrm{m}$. Each image corresponds to the projection of these 20 planes of a sample area of $318 \times 318 \mu \mathrm{m}^{2}$. 


\subsection{Statistical analysis}

The significant difference between means of measured extrusion variables (Table 1) within a grouped samples extruded using same extruder and die configuration was determined by analysis of one-way ANOVA and Fisher's least significant different (LSD). Analysis of one-way ANOVA was also conducted to determine effect of several levels of extrusion variables on protein solubility (Table 3). All statistical analysis were performed at 5\% significance level using Microsoft Excel 2010.

\section{Results and discussion}

Native pea flour contained three major components: starch (46.3\% d.b.), proteins (23.9\% d.b.). The minor components were ash $(2.1 \%$ d.b.) and lipids ( $2 \%$ d.b.). The chemical composition was in the range determined by Li \& Ganjyal (2017) for five varieties of yellow peas. The resulting fiber content was $25.7 \%$ (d.b.).

\subsection{Flour melting, extrusion and expansion}

The measured melting temperature of pea flour $T_{m}$ was $118^{\circ} \mathrm{C}(M C=20 \%$ w.b. $)$, defined as the temperature at peak offset, was slightly higher than those found by Li \& Ganjyal (2017) in the interval $\left[108,113^{\circ} \mathrm{C}\right]$. Variation of melting temperature of pea flour with water volume fraction, was fitted by Flory-Huggins equation, $R^{2}=0.93$ (Appendix, Eq. A1, Fig. A1).

Extrusion parameters and variables are summarized in Table 1. The selected processing conditions, using screw configuration $\mathrm{A}$, resulted in a wide domain of extrusion variables: product temperature $T$ varied between 120 and $165^{\circ} \mathrm{C}, M C$ between 18 and 26\%, and $S M E$ between 400 and $1200 \mathrm{~kJ} / \mathrm{kg}$ (Fig. 1a). The most severe extrusion conditions values corresponding to highest temperature and $S M E$ were obtained for sample $\mathrm{C} 1$ with low moisture content (21.4\%). Conversely, samples E1-E4 were processed at lower temperature $\left(<130^{\circ} \mathrm{C}\right)$ and low $S M E(<100 \mathrm{~kJ} / \mathrm{kg})$ using screw configuration B and larger $M C(\geq 26 \%)$. Under all conditions, product temperature at the die $T$ was higher than $T_{m}$. The extrusion domain exceeded that covered in the previous studies on pea extrusion (Berrios, Tang, \& Swanson, 2008; Hood-Niefer \& Tyler, 2010; Li, Kowalski, Li, \& Ganjyal, 2016; Maskus \& Arntfield, 2015).

Fair correlation $\left(\mathrm{R}^{2}=0.74\right)$ between $T$ and $S M E$ was found, whatever the values of other variables (Fig. 1a). Indeed, higher $T$ and $S M E$ values were obtained for lower $M C$. This general trend, which has not been underlined yet for legume extrusion, is common to starchy products. It is due to the influence of solid friction between flour particles and viscous dissipation in the molten phase (Colonna, Tayeb, \& Mercier, 1989).

The $S M E$ effect on the proteins transformation is complex. The heat due to viscous dissipation can enhance the polymerisation whereas shear causes depolymerisation. Therefore, it is interesting to find how to control $S M E$ by processing parameters. This is illustrated in Fig. 1b, where $S M E$ was plotted as a function of the ratio of total flow rate to screw speed, $Q / N$, which is proportional to the 
filling ratio of screw for a given screw configuration. Good correlation $\left(\mathrm{R}^{2}=0.86\right)$ between $S M E$ and $Q / N$ was obtained for the screw configuration involving reverse elements, whatever $M C$ and die geometry. The same trend was observed in the case of twin-screw extrusion of starchy products: SME increases when screw speed increases and decreases when feed rate is increased (Meuser \& Wiedmann, 1989). Obviously, the SME depends on screw filled length, which changes with screw configuration.

In the applied domain of thermomechanical conditions, the density varied in a large interval $\left(85-1060 \mathrm{~kg} / \mathrm{m}^{3}\right.$, Table 2). Samples extruded with the configuration B (no restrictive elements) were not expanded, likely because of low temperature and $S M E$. They are called dense samples. Extruded samples with density lower than $200 \mathrm{~kg} / \mathrm{m}^{3}$ had similar aspect to directly expanded starchy snacks or foams. Higher expansion is generally preferable because it favours the obtaining of lighter and crispier products.

Density was negatively correlated with product temperature $(T)\left(\mathrm{R}^{2}=0.77\right.$, Fig. 2a). The same trend was observed for $S M E\left(\mathrm{R}^{2}=0.80\right.$ result not shown). On the other hand, $M C$ was correlated positively with foam density $\left(\mathrm{R}^{2}>0.75\right.$ result not shown).

Foam density was inversely related to sectional expansion index $(S E I)\left(\mathrm{R}^{2}=0.91\right)$ for any die geometry (Fig. 2b). This general trend that is known for starchy product extrusion has not been evidenced yet for legumes. Calculation of longitudinal expansion index using Eq. (2), LEI = VEI / SEI, led to $L E I$ values lower than 1 for all pea extrudates. Hence, the volumetric expansion was governed by radial expansion. This result is different from that obtained for starch melts, where increasing die length favoured longitudinal expansion (Kristiawan et al. 2016).

The impact of extrusion variables $(M C, T, S M E)$ on pea flour expansion was the same as on proteinaceous products including legumes (Berrios et al., 2008; Li et al., 2016). However, contrary to starch expansion, the effect of product temperature on pea flour expansion was positive and large (Fig. 2a). Indeed starch expansion is governed by different mechanisms: nucleation, water vaporization, growth, coalescence and shrinkage of gas bubbles in a homogeneous viscous fluid. The influence of temperature on these mechanisms result in opposite effects on final expansion, and thus on density (Kristiawan et al., 2016). The positive influence of temperature on expansion of pea flour by extrusion, suggests that this phenomenon is not only govern by these mechanisms, but also by rheological changes of material structure linked to the morphology of starch-protein composites. Unlike starch melt, pea flour melt cannot be considered as a fully homogenous viscous fluid, this will be discussed in the later discussion about the morphology of parietal material of extrudates (section 3.4).

\subsection{Protein modifications}

Proteins in native flour consisted of a high fraction of SDS-soluble proteins (91.9\%), a low fraction of DTE-soluble proteins $(8.1 \%)$, and no traces of non-extractable proteins. This indicates that 
proteins were mainly linked by non-covalent interactions and less by disulphide bonds. Pea proteins were mainly composed of salt-soluble globulins (45-60\%) and water-soluble albumins (14-30\%), with minor acid/alkali soluble-glutelins and alcohol-soluble prolamines, which explains the high solubility in SDS. The low content in protein DT-soluble can be explained by the poor content of native flour in sulphur containing amino acids such as methionine and cysteine which are able to produce disulphide bonds (Leterme et al., 1990).

According to SE-HPLC elution profile (Fig. 3), SDS-soluble extract was divided into six major fractions: S1 (1.2\%), S2 (6.8\%), S3 (32.3\%), S4a (13.7\%), S4b (17.7\%), and S5 (20.2\%). Pea flour consisted mainly of proteins with intermediate and small sizes having molecular weights ranging from 41 to $91 \mathrm{kDa}$ (S3) and from 9 to $24 \mathrm{kDa}$ (S5) (Barac et al, 2010; Mession, Sok, Assifaoui, \& Saurel, 2013). Albumin 2 (5-80 kDa) can contribute to S3, S4 and S5 fractions. Some of pea globulins $(150-420 \mathrm{kDa})$, i.e. the convicilin $(\sim 290 \mathrm{kDa})$ and vicilin $(\sim 170-180 \mathrm{kDa})$, make a part of S2. Legumins are hexameric proteins with subunit linked by disulphide bonds, 300-420 kDa, which contribute to S2, and Albumin 1 (cysteine-rich peptide, $\sim 10 \mathrm{kDa}$ ) is part of $\mathrm{S} 5$.

Protein solubility of dense samples (E1-E4), extruded at low temperature and SME values was close to that of the native flour (Table 2). With increasing product temperature, beyond $140^{\circ} \mathrm{C}$, SDSsoluble proteins decreased from $95 \%$ to $35 \%\left(\mathrm{R}^{2}=0.83\right.$ ) (Fig. 4a). Conversely, DTE-soluble proteins increased from $5 \%$ to $45 \%$ with temperature $\left(\mathrm{R}^{2}=0.75\right)$. Given the strong correlation between $S M E$ and $T$, the same trends were observed on variations of protein solubility with SME (result not shown). This result indicated the formation of SDS-insoluble protein aggregates via protein cross-linking by disulphide bonds, which was confirmed by the negative correlation between solubility in SDS and DTE $\left(\mathrm{R}^{2}=0.93\right.$, result not shown). The best fitting for solubility variations with temperature was obtained using the sigmoid function (see Fig. $4 a, R^{2} \geq 0.75$ ):

Sol. $=a /\left(1+\exp \left(-k \times\left(T-T_{\mathrm{c}}\right)\right)\right)$

where Sol. is the solubility (in SDS, DTE...), $T$ is the material temperature measured inside the die and $T_{c}$ is the temperature at inflexion point, and $a$ and $k$ are the parameters in sigmoid model (Appendix 3), with

$\operatorname{Sol}\left(T_{c}\right)=a / 2$

and $k$ is linked to the rate and magnitude of solubility change:

$k=4 \times \mathrm{d} S o l / \mathrm{dT}\left(T_{c}\right) / \mathrm{a}$ 
Numerical values of these parameters are summarized in Appendix (Table A1). Onset temperature of the events governing the variation of protein solubility, $T_{i}$, was found using the sigmoid model, see Appendix 3. The loss of protein solubility in SDS started at $146^{\circ} \mathrm{C}$, while the onset of formation of DTE-soluble proteins occurred at $125^{\circ} \mathrm{C}$. The variation of solubility with $S M E$ could be fitted with a similar sigmoid function (result not shown). By subtracting SDS and DTE-soluble proteins from the total protein content in samples $(100 \%)$, the fraction of non-extracted proteins was found. It resulted from the formation of aggregates linked by other covalent bonds than S-S. This fraction could reach up to $26 \%$ (sample C1, Table 1). Formation of these bonds started massively at a temperature close to $152^{\circ} \mathrm{C}$.

The impact of material temperature on size distribution of SDS-soluble proteins of extrudates is illustrated by the variation of fractions identified by SE-HPLC (Fig. 4b). Increasing material temperature led to a marked decrease in the SDS solubility of S1, S2, S3 and S4a fractions following Eqs. (3) $\left(\mathrm{R}^{2}>0.85\right.$, Fig.3). The model parameters are reported in Appendix, Table A1. Conversely, ANOVA analysis showed that protein fraction of $\mathrm{S} 4 \mathrm{~b}$ and $\mathrm{S} 5$ did not vary significantly with temperature (Table 3) and they took average values close to 8.2 and $21.8 \%$, respectively. Each protein fraction had different onset temperature for solubility change, $\mathrm{S} 1$ and $\mathrm{S} 2: 151^{\circ} \mathrm{C}, \mathrm{S} 3: 135^{\circ} \mathrm{C}$, and $\mathrm{S} 4 \mathrm{a}$ : $147^{\circ} \mathrm{C}$, and $S M E$ in the range $550-600 \mathrm{~kJ} / \mathrm{kg}$. These values are closed to those for the formation of protein aggregates linked by S-S $\left(125^{\circ} \mathrm{C} ; 625 \mathrm{~kJ} / \mathrm{kg}\right)$ and other covalent bonds $\left(152^{\circ} \mathrm{C}, 550 \mathrm{~kJ} / \mathrm{kg}\right)$ (Fig. 4a). As expected, the SDS solubility of S3, S3 and S4a fractions decreases with increasing DTEsoluble and non-extractable proteins, which shows that these fractions become insoluble with the formation of S-S and other covalent bonds.

Thermal induced protein in-solubilisation due to S-S cross-linking has been reported for extrusion of legumes (Alonso et al., 2000; Laleg, Cassan, Barron, Prabhasankar, \& Micard, 2016; Stanley, 1989) and gluten (Pommet, Redl, Morel, Domenek, \& Guilbert, 2003). Increasing SME favoured proteins cross-linking by S-S and non S-S covalent bonds due to the enhancement of unfolding and re-association of protein aggregates under high shear force (Anderson \& Ng, 2000; Camire, 1991; Della Valle et al., 1994). Although $S M E$ is directly correlated to $T$ because of solid friction and viscous dissipation, our results suggest that it is the temperature which influenced directly these changes. Moreover, the ANOVA analysis did not show any significant effect of die geometry (configuration C and D) on protein solubility (Table 3), probably because shear did not contribute to protein transformation. The close protein transformations between two die geometries mean that the main structural changes happened in the screw extruder section and no further changes occurred in long die. ANOVA analysis also demonstrated that there was insignificant effect of moisture content on protein changes for the three conditions $(0.18 ; 0.21 ; 0.26)$ (Table 3$)$. The material temperature corresponding to the onsets of proteins cross-linking during extrusion of pea flour were determined for the first time. Both S-S and non S-S covalent bonds contributed to protein in-solubilisation. Della Valle et al. (1994) pretended that the role of S-S was less important than other covalent bonding based 
on the fact that protein aggregates with S-S bonds did not vary much with extrusion conditions. This discrepancy can be attributed to different methods of protein extraction and quantification. In the earlier works, neither sonication-assisted extraction procedure nor precise SE-HPLC for solubleprotein quantification was performed. Moreover, different reagents (DTT in citrate phosphate buffer vs. DTE in SDS-phosphate buffer) and extraction temperature were implemented to disrupt S-S bonds. The use of DTT in the absence appropriate denaturant (urea, guanidine, or SDS) is less effective because it cannot reduce buried (solvent-inaccessible) disulfide bonds (Hermanson, 2013).

\subsection{Total solubility, color and starch changes}

Native pea flour displayed peaks at $5.6^{\circ}, 9.8^{\circ}, 11.3^{\circ}, 15.2^{\circ}, 17^{\circ}, 18.2^{\circ}, 21.9^{\circ}, 23^{\circ}$ and $26.3^{\circ}$ on the WAXS diffractograms (Fig. 5a). These peaks are typical for C-type crystallinity pattern of starch from legumes (Buleon, Gerard, Riekel, Vuong, \& Chanzy, 1998). For extruded samples, these peaks have disappeared, which suggested that starch was amorphous. This is in agreement with the values of $T$, always larger than $T_{m}$ (see 3.1). The absence of DSC residual gelatinisation (Fig. 5b) confirmed that the extruded samples were amorphous.

The water solubility index of total solids $W S I_{\text {solids }}$ of flour and extrudates took into account starch and other soluble components like fibers and proteins. $W S I_{\text {solids }}$ was correlated positively with that of starch $\left(\mathrm{R}^{2}=0.81\right.$, result not shown). As protein aggregates resulting from cross-linking of water soluble proteins were not soluble in water, and since only $1.1 \%$ (d.b.) of total fibers (13.4\% d.b.) in native split pea flour was water soluble (Petitot, Barron, Morel, \& Micard, 2010), we supposed that fibers, the third major component in pea flour, were solubilized during extrusion (Ralet, Della Valle, \& Thibault, 1993).

Extruded starches were partially soluble with WSI 50\%, i.e. lower than WSI of solids. Both indices increased with temperature (Fig. 6), and also with SME (result not shown). Both temperature and shear energy are known to increase the breakdown of starch granules and macromolecules and subsequently to raise the amount of water-soluble components (from 12 to 55\%) compared to starch in native flour (11.7\%). Moreover, WSI of total solids was negatively and linearly correlated with WAI $\left(\mathrm{R}^{2}=0.83\right.$, result not shown), suggesting that extrudates that are less soluble in water may absorb more water. Higher WAI indicates the presence of larger starch granule fragments, while higher WSI implies that starch was depolymerized (de Mesa et al., 2009; Kirby, Ollett, Parker, \& Smith, 1988). These results are rather confirmatory, since they are common to extrusion of starches (Chinnaswamy \& Hanna, 1990). However, Mercier and Feillet (1975) reported that in the temperature domain [90; $250^{\circ} \mathrm{C}$ ] WAI of extruded corn starch increased with $W S I$, reaching maximum at $175^{\circ} \mathrm{C}$. We found that the increase of both WSI indices with material temperature could be fitted sufficiently with sigmoid model (Fig. 6). This model allowed determination of onset temperature of starch solubility increase, close to $115^{\circ} \mathrm{C}$. This value is lower than the onset temperatures of protein solubility decrease and formation of S-S bonds. The interval between onset temperature of starch and protein changes can be 
considered as experimental window to obtain extruded products having sufficient soluble starch and to avoid massive in-solubilisation of proteins.

Extruded materials were darker as shown by the decrease of $L^{*}$ values from 87 to 58 and more reddish and bluish (higher $a^{*}$ and lower $b^{*}$ ) with increase of $T$ (Fig. 7a). Moreover, correlations of $a^{*}$ with protein solubility in DTE $\left(\mathrm{R}^{2}=0.80\right)$ and non-extractable proteins $\left(\mathrm{R}^{2}=0.80\right)$ showed that protein aggregations by other covalent bonds occurred at the same time as darkening and increase in redness, i.e. browing (Fig. 7b). Extrudate browning can be related to the development of Maillard reactions between reducing sugars and free amine groups (lysine). Reducing sugars can result from starch breakdown during extrusion (Camire, 1991). The higher intensity of thermo-mechanical treatment, the higher was the transformation of starch and proteins and the interactions between their derivatives. Consequently, Maillard reactions can be related to the reduction of lysine availability in the extruded pea (Asp \& Björck, 1989; Meuser \& Wiedmann, 1989). Lysine is one of the most sensitive and most limiting amino acids in humane diets, so lysine availability is one of nutritional quality criteria for processed legumes (Asp \& Björck, 1989; Hood-Niefer and Tyler, 2010; Laleg et al., 2017). Finally, extrudate color can be utilised as indicator of protein aggregation by covalent linkages others than S-S ones; in a first approach for sample screening before analysis of protein solubility using SE-HPLC.

\subsection{Cell wall morphology}

The morphology of starch-protein blend in the cell wall materials of expanded samples was ascertained using CSLM for two samples extruded at similar $T$, higher than the onset of proteins aggregation by S-S bonds: sample C12 $\left(550 \mathrm{~kJ} / \mathrm{kg}, 136^{\circ} \mathrm{C}\right)$ and D11 $\left(720 \mathrm{~kJ} / \mathrm{kg}, 140^{\circ} \mathrm{C}\right)$. Sample D11 had slightly higher starch and DTE-protein solubility, likely due to higher SME. For C12 (Fig. 8a). CSLM micrograph shows small protein aggregates $(\approx 10 \mu \mathrm{m}$, green) dispersed among some swollen and stretched starch granules ("ghosts", $\approx 50 \mu \mathrm{m}$, light red), and entrapped in a continuous reddish network, formed by dispersed starch macromolecules. Conversely, CSLM of sample D11 (Fig. 8b) revealed larger stretched protein aggregates connected together $(30-50 \mu \mathrm{m}$, green) and forming morphology of co-continuous phases with starch macromolecules (reddish), with much less swollen granules. In both cases, the presence of swollen granules and dispersed starch phase was expected, since starch was amorphous and solubility index was about 35\%. Together with preceding results (3.2 and 3.3) these images suggest that different states of protein aggregations can lead to various starchprotein morphologies. Hence the composite morphology of the cell wall of expanded pea flour would be governed by the size and continuity of protein aggregates. Their presence may lead to a continuous protein phase which can limit the access of water to starch, and explain the lower values of starch swelling and solubility in pea flour compared to the pure starch with WSI as high as $100 \%$ (Meuser, van Lengerich, \& Reimers, 1984). Moreover, these results confirmed that pea flour cannot be considered as a homogenous viscous fluid during extrusion, as suggested in chapter 3.1, and they 
could explain the difficulties encountered when measuring its melt viscosity under thermomechanical conditions close to those of extrusion (Beck, Knoerzer, Sellahewa, Emin, \& Arcot, 2017).

The changes of morphology can affect the viscosity of the pea flour during extrusion and modify its behaviour during expansion. Although extrusion conditions $(S M E, T)$ were very close to each other, density values (103 vs $439 \mathrm{~kg} / \mathrm{m}^{3}$, see Table 2) indicated that sample D11 was much more expanded than C12. Expansion during extrusion involves the succession of various mechanisms and the influence of extrusion variables on these mechanisms has been recently reviewed (Kristiawan et al., 2016). By increasing interface area between protein aggregates and amorphous starch, like in the case of the co-continuous phases (sample D11), bubble nucleation is increased which favours expansion. Moreover, for composite morphology, bubble coalescence can be reduced because of increased elongational viscosity of the melts, as shown by results for starch/zein composites (Chanvrier, Chaunier, Della Valle, \& Lourdin, 2015; Chanvrier, Della Valle, \& Lourdin, 2006). These authors found that the starch-protein blends with co-continuous phases morphology of (like sample D11) had higher elongational viscosity than the blends with the morphology of particles dispersed in a matrix (sample C12). This interpretation was comforted by the fact that sample D11 was extruded with the circular die $\mathrm{D}$, where, due to section contraction, elongational strains were larger than for the slit die $\mathrm{C}$ with prevailing shear. Clearly, this interpretation has to be confirmed by studying the rheological behaviour of pea flour envisioned like a composite material of protein aggregates with amorphous starch and by ascertaining the morphology of these materials.

\section{Conclusion}

The large domain of hydro-thermo-mechanical conditions of pea flour extrusion led to a large panel of starch and protein chemical changes, and of morphologies of the foams cell wall material. Multi-scale structural analyses have shown that protein and starch changes depend mainly on material temperature during extrusion. With increasing intensity of thermo-mechanical treatment starch solubility in water increased, and protein solubility in SDS decreased due to the formation of protein aggregates linked by disulphide and other covalent bonds. The onset of proteins changes occurred in the interval $\left[125,146^{\circ} \mathrm{C}\right]$ while that of starch solubility took place at lower temperature $\left(115^{\circ} \mathrm{C}\right)$. The interval $\left[115,146^{\circ} \mathrm{C}\right]$ can be suggested as temperature domain allowing to design extruded products having sufficient soluble starch without massive insolubilisation of proteins. At close values of $T$ and $S M E$, die geometry affects expansion by modifying the starch/protein composite morphology constituting the cell wall material of the extrudate, from dispersed small protein aggregates to a bicontinuous matrix between large protein aggregates and amorphous starch.

These trends will be ascertained in future work by focusing on the rheological behaviour of composite material by taking into account the influence of other constituents of flour (fiber, lipid) on morphology. This approach will help the modelling of pea flour expansion by extrusion, and designing cellular structure for target texture properties. 


\section{Acknowle dgements}

Authors are thankful to Joëlle Bonicel (INRA-IATE) for protein SE-HPLC analysis, Roselyne Desirest and Bruno Pontoire (INRA-BIA), and Kerstin Sauther and Andrea Butterbrodt (KIT) for excellent technical assistance.

\section{References}

Alonso, R., Orue, E., Zabalza, M. J., Grant, G., \& Marzo, F. (2000). Effect of extrusion cooking on structure and functional properties of pea and kidney bean proteins. Journal of the Science of Food and Agriculture, 80(3), 397-403.

Anderson, A. K., \& Ng, P. K. W. (2000). Changes in disulfide and sulfhydryl contents and electrophoretic patterns of extruded wheat flour proteins. Cereal Chemistry Journal, 77(3), 354-359.

Anderson, R. A., Conway, H. F., \& Peplinski, A. J. (1970). Gelatinization of corn grits by roll cooking, extrusion cooking and steaming. Starke, 22(4), 130-135.

Asp, N.-G., \& Björck, I. (1989). Nutritional properties of extruded foods. In C. Mercier, P. Linko, \& J. M. Harper (Eds.), Extrusion cooking (pp. 399-434). St. Paul, Minnesota, USA: American Association of Cereal Chemists, Inc.

Barac, M., Cabrilo, S., Pesic, M., Stanojevic, S., Zilic, S., Macej, O., \& Ristic, N. (2010). Profile and functional properties of seed proteins from six pea (Pisum sativum) genotypes. International Journal of Molecular Sciences, 11(12), 4974-4991.

Barron, C., Buleon, A., Colonna, P., \& Della Valle, G. (2000). Structural modifications of low hydrated pea starch subjected to high thermomechanical processing. Carbohydrate Polymers, 43(2), 171-181.

Beck, S. M., Knoerzer, K., Sellahewa, J., Emin, M. A., \& Arcot, J. (2017). Effect of different heat-treatment times and applied shear on secondary structure, molecular weight distribution, solubility and rheological properties of pea protein isolate as investigated by capillary rheometry. Journal of Food Engineering, 208, 66-76.

Ben-Hdech, H., Gallant, D. J., Bouchet, B., Gueguen, J., \& Melcion, J.-P. (1991). Extrusioncooking of pea flour: Structural and immunocytochemical aspects. Food structure, 10(3), 203-212.

Berrios, J. J., Tang, J., \& Swanson, B. G. (2008). Extruded legumes. US Patent 2008/0145483 Al, 1-16.

Buleon, A., Gerard, C., Riekel, C., Vuong, R., \& Chanzy, H. (1998). Details of the crystalline ultrastructure of $\mathrm{C}$-starch granules revealed by synchrotron microfocus mapping. Macromolecules, 31(19), 6605-6610.

Camire, M. E. (1991). Protein functionality modification by extrusion cooking. Journal of the American Oil Chemists' Society, 68(3), 200-205. 
Chanvrier, H., Colonna, P., Della Valle, G., \& Lourdin, D. (2005). Structure and mechanical behaviour of corn flour and starch-zein based materials in the glassy state. Carbohydrate Polymers, 59(1), 109-119.

Chanvrier, H., Della Valle, G., \& Lourdin, D. (2006). Mechanical behaviour of corn flour and starch-zein based materials in the glassy state: A matrix-particle interpretation. Carbohydrate Polymers, 65(3), 346-356.

Chanvrier, H., Chaunier, L., Della Valle, G., \& Lourdin, D. (2015). Flow and foam properties of extruded maize flour and its biopolymer blends expanded by microwave. Food Research International, 76, 567-575.

Chinnaswamy, R., \& Hanna, M. A. (1990). Macromolecular and functional properties of native and extrusion-cooked corn starch. Cereal Chemistry, 67(5), 490-499.

Colonna, P., Tayeb, J., \& Mercier, C. (1989). Extrusion cooking of starch and starchy products. In C. Mercier, P. Linko, \& J. M. Harper (Eds.), Extrusion cooking (pp. 247-319). St. Paul, Minnesota, USA: American Association of Cereal Chemists, Inc.

Day, L., \& Swanson, B. G. (2013). Functionality of protein-fortified extrudates. Comprehensive Reviews in Food Science and Food Safety, 12(5), 546-564.

de Mesa, N. J. E., Alavi, S., Singh, N., Shi, Y. C., Dogan, H., \& Sang, Y. J. (2009). Soy protein-fortified expanded extrudates: Baseline study using normal corn starch. Journal of Food Engineering, 90(2), 262-270.

Della Valle, G., Quillien, L., \& Gueguen, J. (1994). Relationships between processing conditions and starch and protein modifications during extrusion-cooking of pea flour. Journal of the Science of Food and Agriculture, 64(4), 509-517.

El-Adawy, T. A., Rahma, E. H., El-Bedawey, A. A., \& El-Beltagy, A. E. (2003). Nutritional potential and functional properties of germinated mung bean, pea and lentil seeds. Plant Foods for Human Nutrition, 58(3), 1-13.

Fang, Y., Zhang, B., Wei, Y., \& Li, S. (2013). Effects of specific mechanical energy on soy protein aggregation during extrusion process studied by size exclusion chromatography coupled with multi-angle laser light scattering. Journal of Food Engineering, 115(2), 220-225.

Folch, J., Lees, M., \& Stanley, G. H. S. (1957). A simple method for the isolation and purification of total lipides from animal tissues. Journal of Biological Chemistry, 226(1), 497-509.

Gujska, E., \& Khan, K. (1991). High temperature extrusion effects on protein solubility and distribution in navy and pinto beans. Journal of Food Science, 56(4), 1013-1016.

Hermanson, G. T. (2013). Chapter 2 - Functional Targets for Bioconjugation. In Bioconjugate Techniques (Third edition) (pp. 127-228). Boston: Academic Press.

Holay, S. H., \& Harper, J. M. (1982). Influenece of the extrusion shear environment on plant protein texturization. Journal of Food Science, 47(6), 1869-1874. 
Hood-Niefer, S. D., \& Tyler, R. T. (2010). Effect of protein, moisture content and barrel temperature on the physicochemical characteristics of pea flour extrudates. Food Research International, 43(2), 659-663.

Kirby, A. R., Ollett, A. L., Parker, R., \& Smith, A. C. (1988). An experimental study of screw configuration effects in the twin-screw extrusion-cooking of maize grits. Journal of Food Engineering, $8(4), 247-272$.

Kristiawan, M., Chaunier, L., Della Valle, G., Ndiaye, A., \& Vergnes, B. (2016). Modeling of starchy melts expansion by extrusion. Trends in Food Science \& Technology, 48, 13-26.

Laleg, K., Cassan, D., Barron, C., Prabhasankar, P., \& Micard, V. (2016). Structural, culinary, nutritional and anti-nutritional properties of high protein, gluten Free, 100\% legume Pasta. Plos One, 11(9), 1-19.

Laleg, K., Barron, C., Cordelle, S., Schlich, P., Walrand, S., \& Micard, V. (2017). How the structure, nutritional and sensory attributes of pasta made from legume flour is affected by the proportion of legume protein. LWT - Food Science and Technology, 79, 471-478.

Logié, N., Della Valle, G., Rolland-Sabaté, A., Descamps, N., \& Soulestin, J. (2018). How does temperature govern mechanisms of starch changes during extrusion? Carbohydrate Polymers, 184, 57-65.

Mercier, C., \& Feillet, P. (1975). Modification of carbohydrate components by extrusioncooking of cereal products. Cereal Chemistry, 52(3), 283-297.

Leterme, P., Monmart, T., \& Baudart, E. (1990). Amino acid composition of pea (Pisum sativum) proteins and protein profile of pea flour. Journal of the Science of Food and Agriculture, 53(1), 107-110.

Li, C., Kowalski, R. J., Li, L., \& Ganjyal, G. M. (2016). Extrusion expansion characteristics of samples of select varieties of whole yellow and green dry pea flours. Cereal Chemistry Journal, 94(3), 385-391.

Li, C. J., \& Ganjyal, G. M. (2017). Chemical composition, pasting, and thermal properties of 22 different varieties of peas and lentils. Cereal Chemistry, 94(3), 392-399.

Maskus, H., \& Arntfield, S. (2015). Extrusion processing and evaluation of an expanded, puffed pea snack product. Journal of Nutrition \& Food Sciences, 5(4), 378.

Mession, J. L., Sok, N., Assifaoui, A., \& Saurel, R. (2013). Thermal denaturation of pea globulins (Pisum sativum L.)-Molecular interactions leading to heat-induced protein aggregation. Journal of Agricultural and Food Chemistry, 61(6), 1196-1204.

Meuser, F., van Lengerich, B., \& Reimers, H. (1984). Kochextrusion von stärken. Vergleich experimenteller ergebnisse zwischen laborextrudern und produktionsextrudern mittels systemanalyse. Starch - Stärke, 36(6), 194-199. 
Meuser, F., \& Wiedmann, W. (1989). Extrusion plant design. In C. Mercier, P. Linko, \& J. M. Harper (Eds.), Extrusion cooking (pp. 91-155). St. Paul, Minnesota, USA: American Association of Cereal Chemists, Inc.

Morel, M. H., Dehlon, P., Autran, J. C., Leygue, J. P., \& Bar-L'Helgouac'h, C. (2000). Effects of temperature, sonication time, and power settings on size distribution and extractability of total wheat flour proteins as determined by size-exclusion high-performance liquid chromatography. Cereal Chemistry, 77(5), 685-691.

Paton, D., \& Spratt, W. A. (1984). Component interactions in the extrusion cooking process: Influence of process conditions on the functional viscosity of the wheat flour system. Journal of Food Science, 49(5), 1380-1385.

Petitot, M., Barron, C., Morel, M. H., \& Micard, V. (2010). Impact of legume flour addition on pasta structure: Consequences on its in vitro starch digestibility. Food Biophysics, 5(4), 284-299.

Pommet, M., Redl, A., Morel, M.-H., Domenek, S., \& Guilbert, S. (2003). Thermoplastic processing of protein-based bioplastics: chemical engineering aspects of mixing, extrusion and hot molding. Macromolecular Symposia, 197(1), 207-218.

Ralet, M. C., Della Valle, G., \& Thibault, J. F. (1993). Raw and extruded fibre from pea hulls. Part I: Composition and physico-chemical properties. Carbohydrate Polymers, 20(1), 17-23.

Redl, A., Morel, M. H., Bonicel, J., Vergnes, B., \& Guilbert, S. (1999). Extrusion of wheat gluten plasticized with glycerol: Influence of process conditions on flow behavior, rheological properties, and molecular size distribution. Cereal Chemistry, 76(3), 361-370.

Stanley, W. D. (1989). Protein reactions during extrusion processing. In C. Mercier, P. Linko, \& J. M. Harper (Eds.), Extrusion cooking (pp. 321-341). St. Paul, Minnesota, USA: American Association of Cereal Chemists, Inc.

Tollier, M. T., \& Robin, J. P. (1979). Adaptation de la méthode à l'orcinol sulfurique au dosage automatique des glucides neutres totaux: conditions d'application aux extraits d'origine végétale. Annales de Technologie Agricole, 28, 1-15.

Tolstoguzov, V. B. (2016). Creation of fibrous structures by spinneretless spinning. In J. M. V. Blanshard, \& J. R. Mitchell (Eds.), Food structure: its creation and evaluation (pp; 181-196). London, UK: Elsevier Science.

Vergnes, B., Della Valle, G., \& Delamare, L. (1998). A global computer software for polymer flows in corotating twin screw extruders. Polymer Engineering and Science, 38(11), 1781-1792.

\section{Figure captions}

Fig. 1. Domaine of extrusion variables: moisture content $(M C)$, product temperature $(T)$ and specific mechanical energy $(S M E)$

(a) Variation of $T$ with $S M E$. Data dispersion is due to differences in die configuration, imposed die temperature, and total mass flow rate. 
(b) Variation of $S M E$ with filling ratio for specified screw configuration. The filling ratio is total mass flow rate $(Q)$ divided by screw speed $(N)$

The symbols refer to measured data, and the solid lines represent data fitting using Eqs.: $T=m \times S M E+b$ (Fig. 1a), and $S M E=b_{1} \times(Q / N)^{b_{2}}$ (Fig. 1b). The fitting equations are shown in the Appendix (Table A1)

Fig. 2. Macro structure of pea extrudates

(a) Variation of density $\left(\rho^{*}\right)$ with product temperature

(b) Relation between sectional expansion index (SEI) and density

The symbols refer to measured data, and the solid lines represent data fitting using Eqs.: $\rho^{*}=$ $a /\left(1+\exp \left(-k \times\left(T-T_{c}\right)\right)\right)$ (Fig. 2a), and $S E I=b_{1} \times \rho^{*\left(b_{2}\right)}$ (Fig. 2b). The fitting equations are shown in the Appendix (Table A1)

Fig. 3. SE-HPLC elution profile of SDS-soluble proteins of pea flour and extrudates (C2 and C12) at different extrusion temperature

Fig. 4. Variation of protein transformation with product temperature

(a) Protein solubility in buffers (SDS and DTE)

(b) SDS-soluble protein fractions

The open symbols refer to measured data of flour while the closed ones for extrudates. The solid lines represent data fitting using Eq. 3a: Sol. $=a /\left(1+\exp \left(-k \times\left(T-T_{c}\right)\right)\right)$.

Sol. indicates either soluble proteins in specified reagents (Fig. 4a) or SDS-soluble protein fractions (Fig. 4b). $T_{i}$ is the temperature at the onset of solubility change. The fitting equation is shown in the Appendix (Table A1)

Fig. 5. Amorphous extruded samples

(a) Absence of crystallinity peaks in WAXS spectrum

(b) Absence of DSC gelatinisation enthalpy

Fig. 6. Variation of water solubility index (WSI) of pea extrudates with product temperature. WSI of solids and WSI of starch are fitted with different curves using Eq.: $W S I=a /(1+\exp (-k \times(T-$ $\left.\left.T_{c}\right)\right)$ ). $T_{i}$ is the temperature of the onset of WSI change. The fitting parameters are shown in the Appendix (Table A1)

Fig. 7. Relation between protein solubility and Maillard reactions 
(a) Variation of extrudate color with product temperature

(b) Variation of protein solubility in buffers with extrudate color

The symbols refer to measured data, and the solid lines represent data fitting using Eqs.: $L^{*}, a^{*}, b^{*}=$ $a /\left(1+\exp \left(-k \times\left(T-T_{c}\right)\right)\right)\left(\right.$ Fig. 7a), and Sol.DTE $=a /\left(1+\exp \left(-k \times\left(T-T_{c}\right)\right)\right)$ and non extrac. $=m \times a^{*}+b$ (Fig. 7b). Sol. DTE indicates DTE-soluble proteins while non-extrac. refers to non-extractable proteins. The fitting equations are shown in the Appendix (Table A1)

Fig. 8. CSLM images of cell wall of foams, extruded at close $T$ values $\left(138^{\circ} \mathrm{C}+/-2^{\circ} \mathrm{C}\right)$. Proteins were stained as green with fuchsin acid. Starch was stained red with PPA.

The morphology of cell wall changed from dispersed small protein aggregates embedding some swelled starches (Fig. 8a) to a bi-continuous matrix between large protein aggregates and amorphous $\operatorname{starch}$ (Fig. 8b). 
(a)

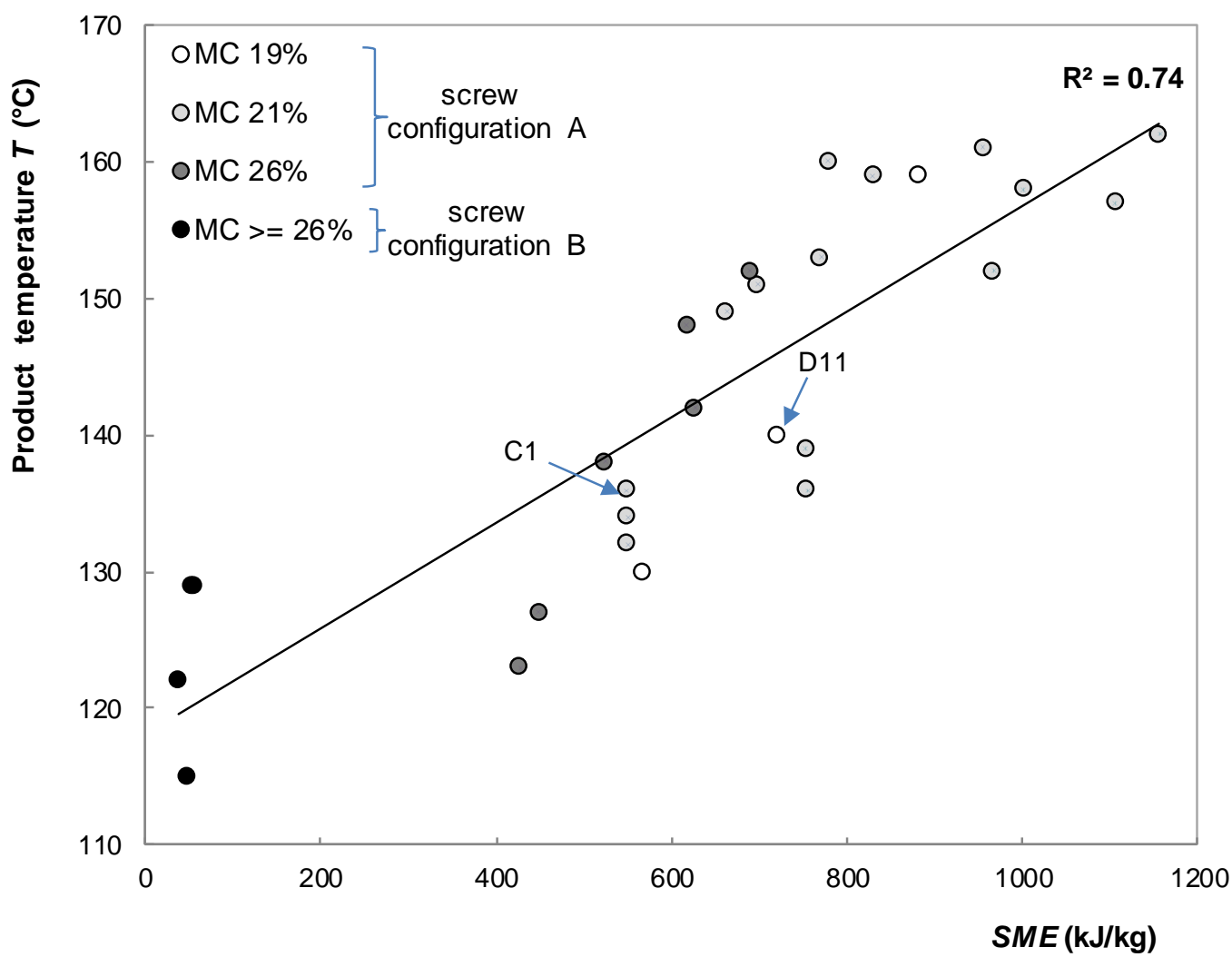

(b)

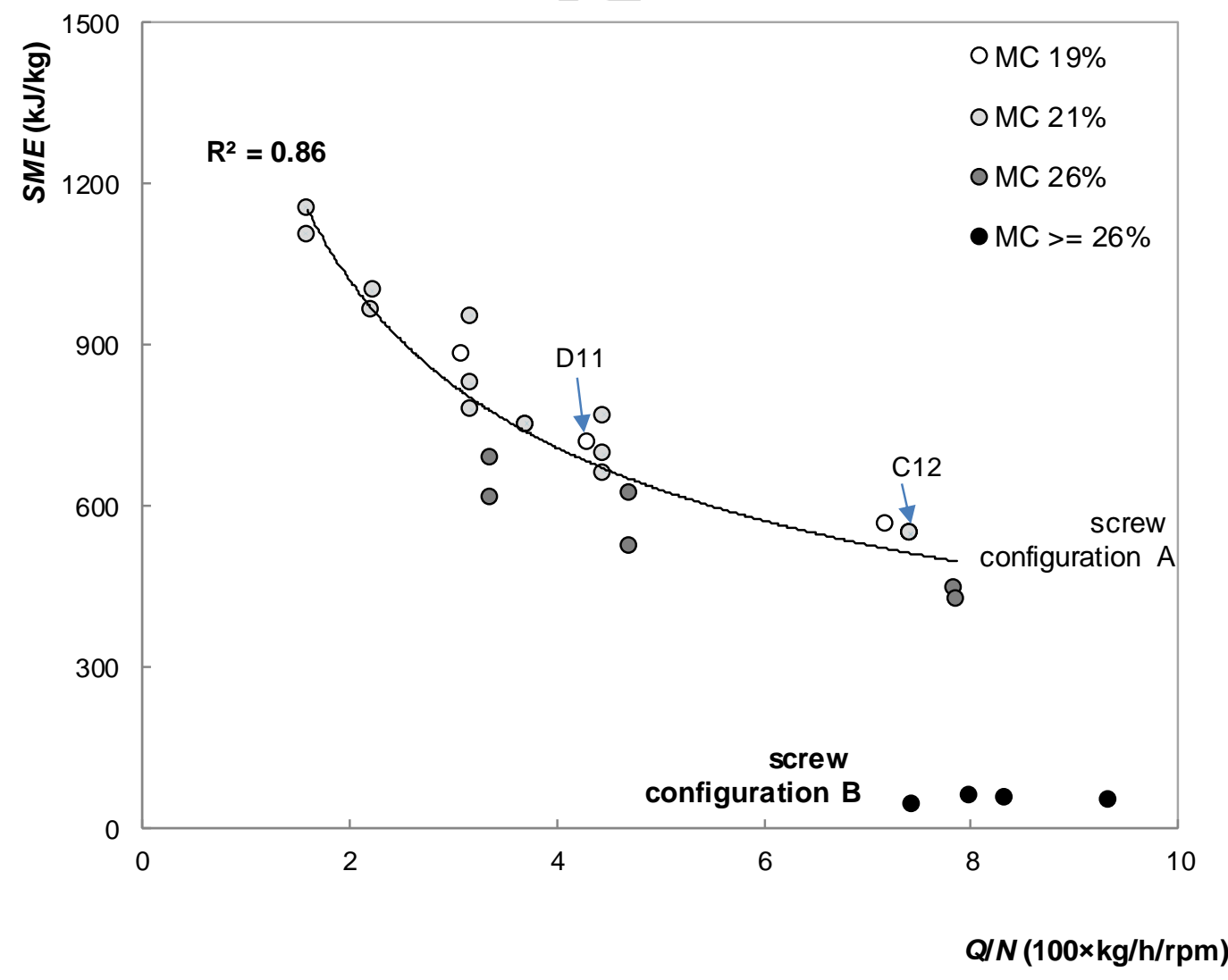

Fig. 1. 
(a)

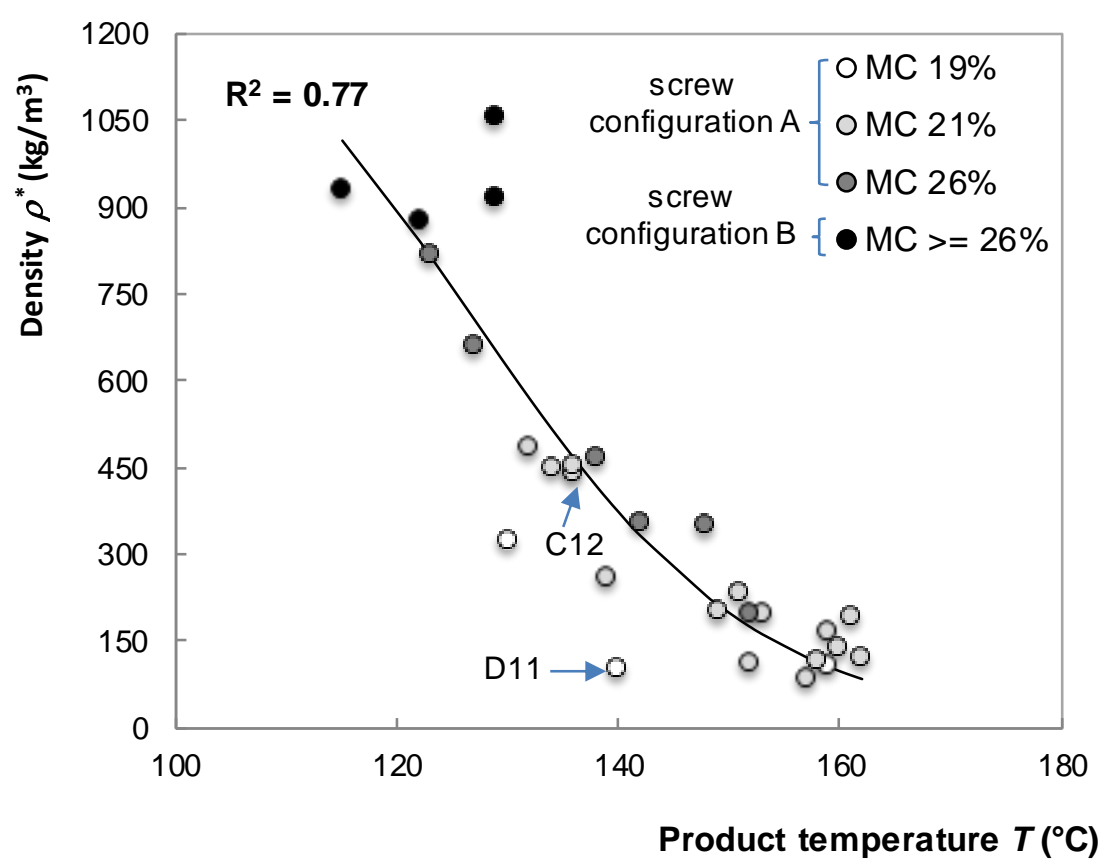

(b)

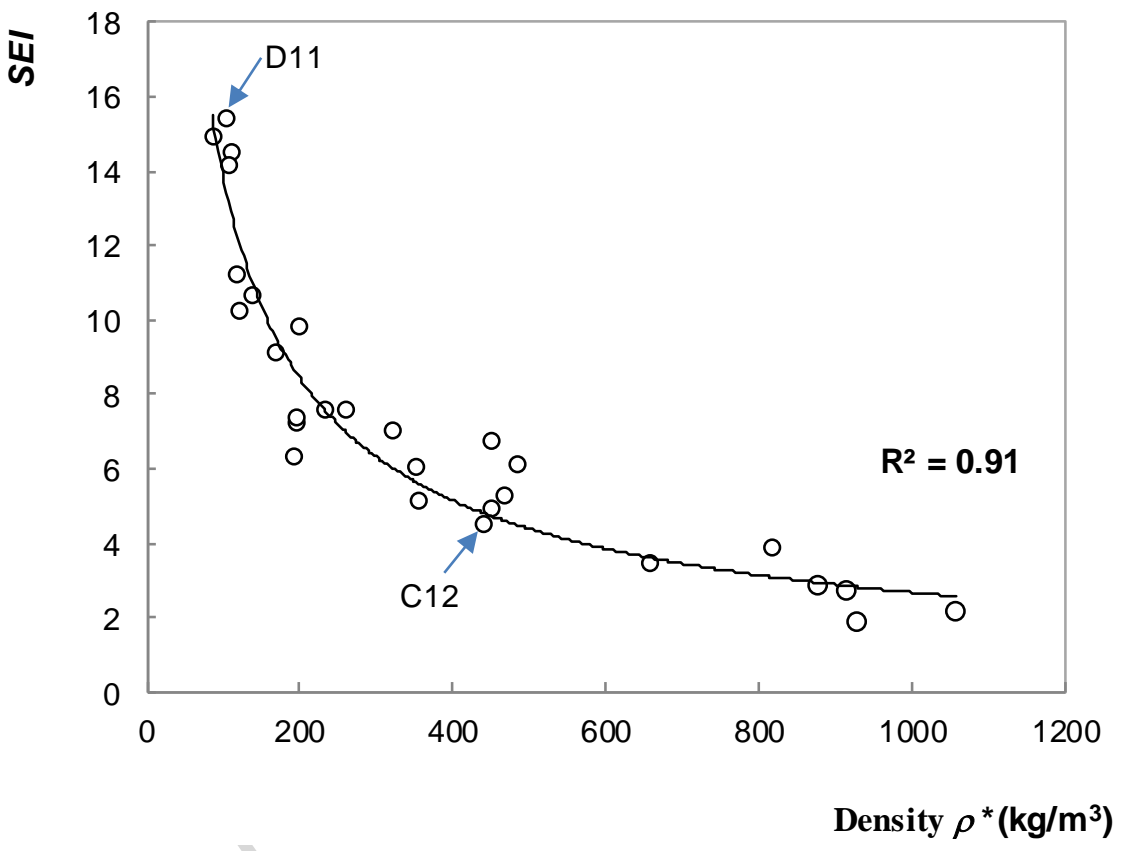

Fig. 2. 


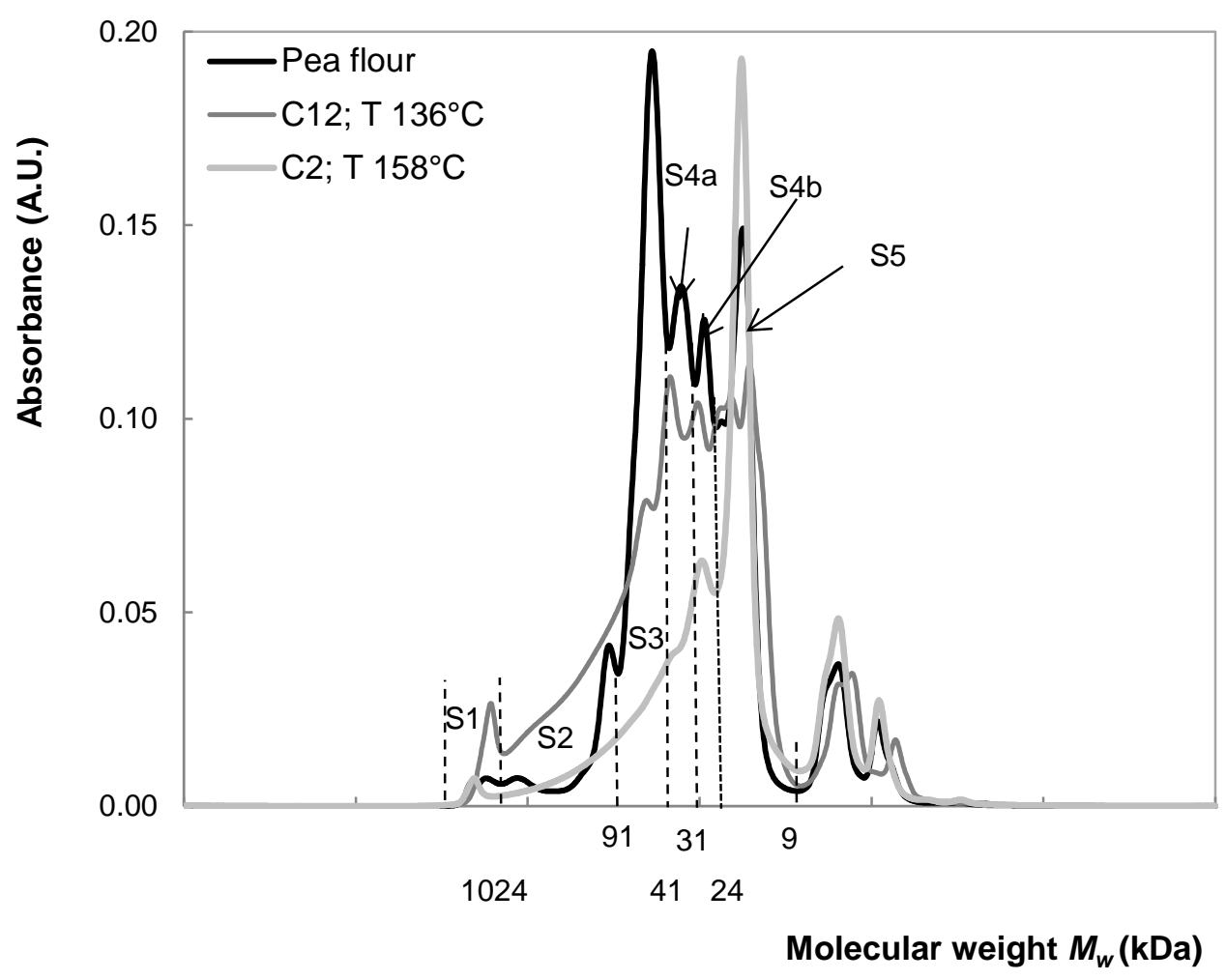

Fig. 3. 
(a)

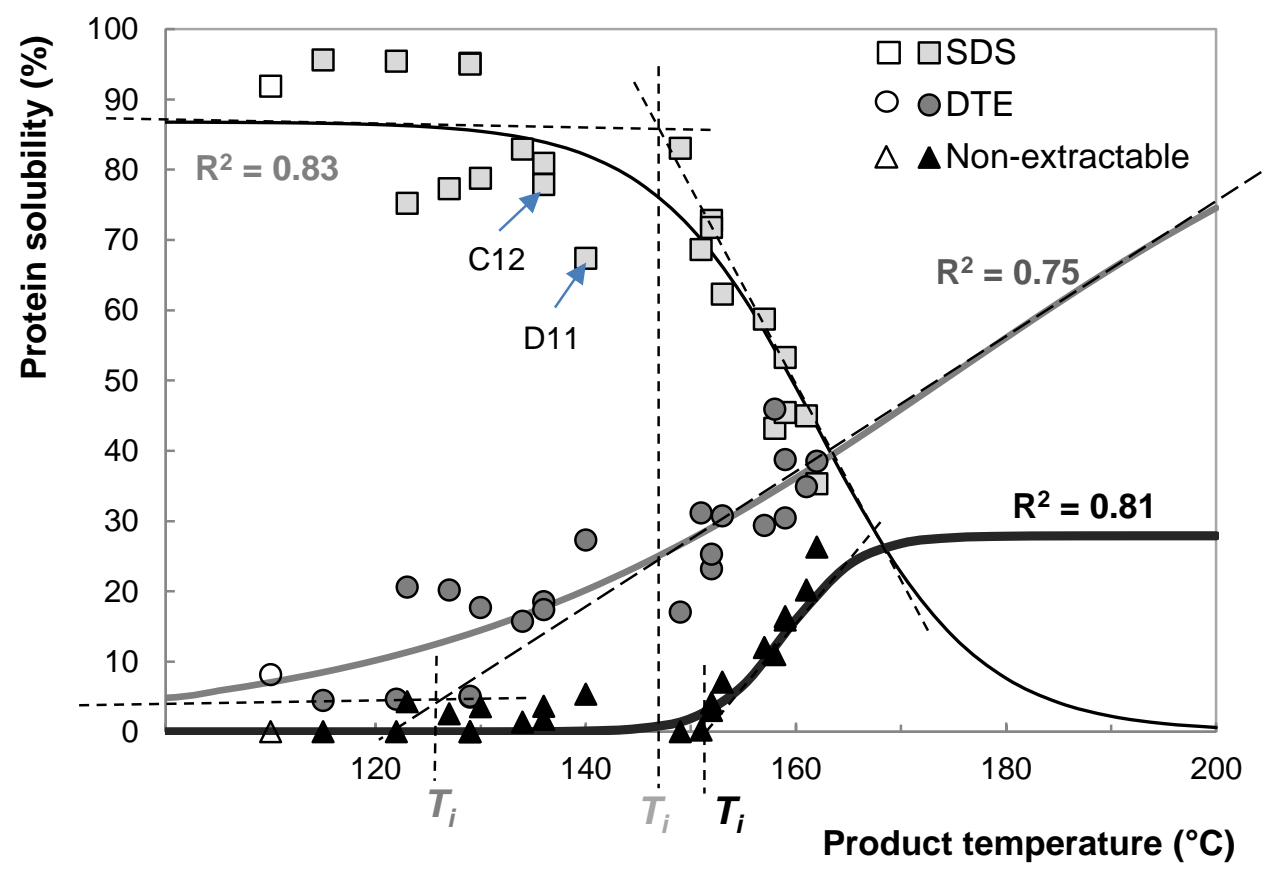

(b)

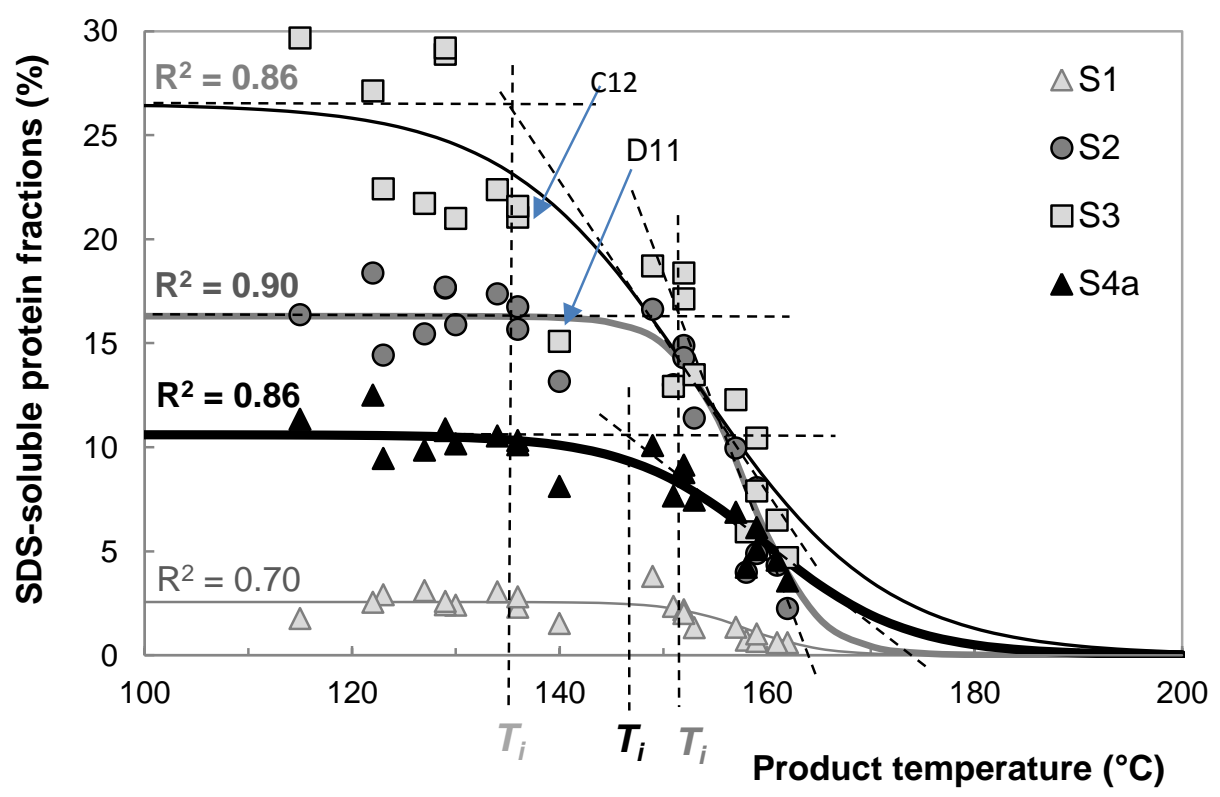

Fig. 4. 
(a)

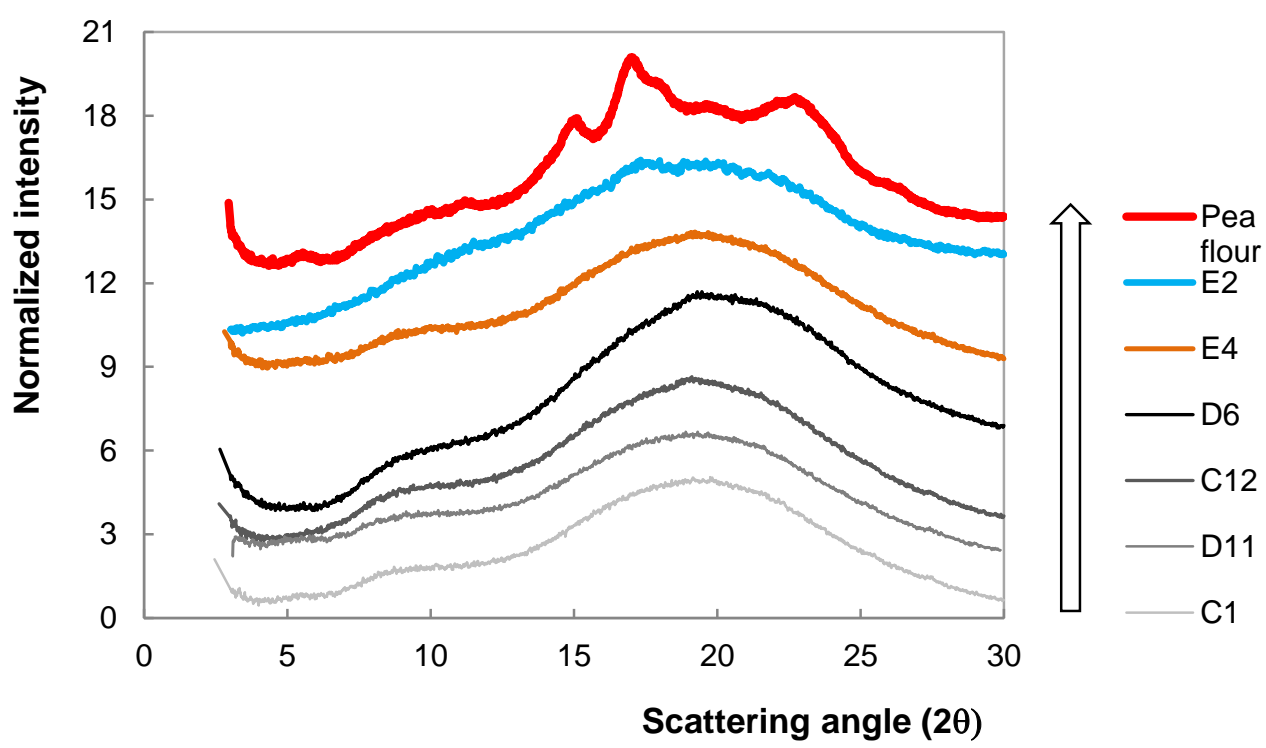

(b)

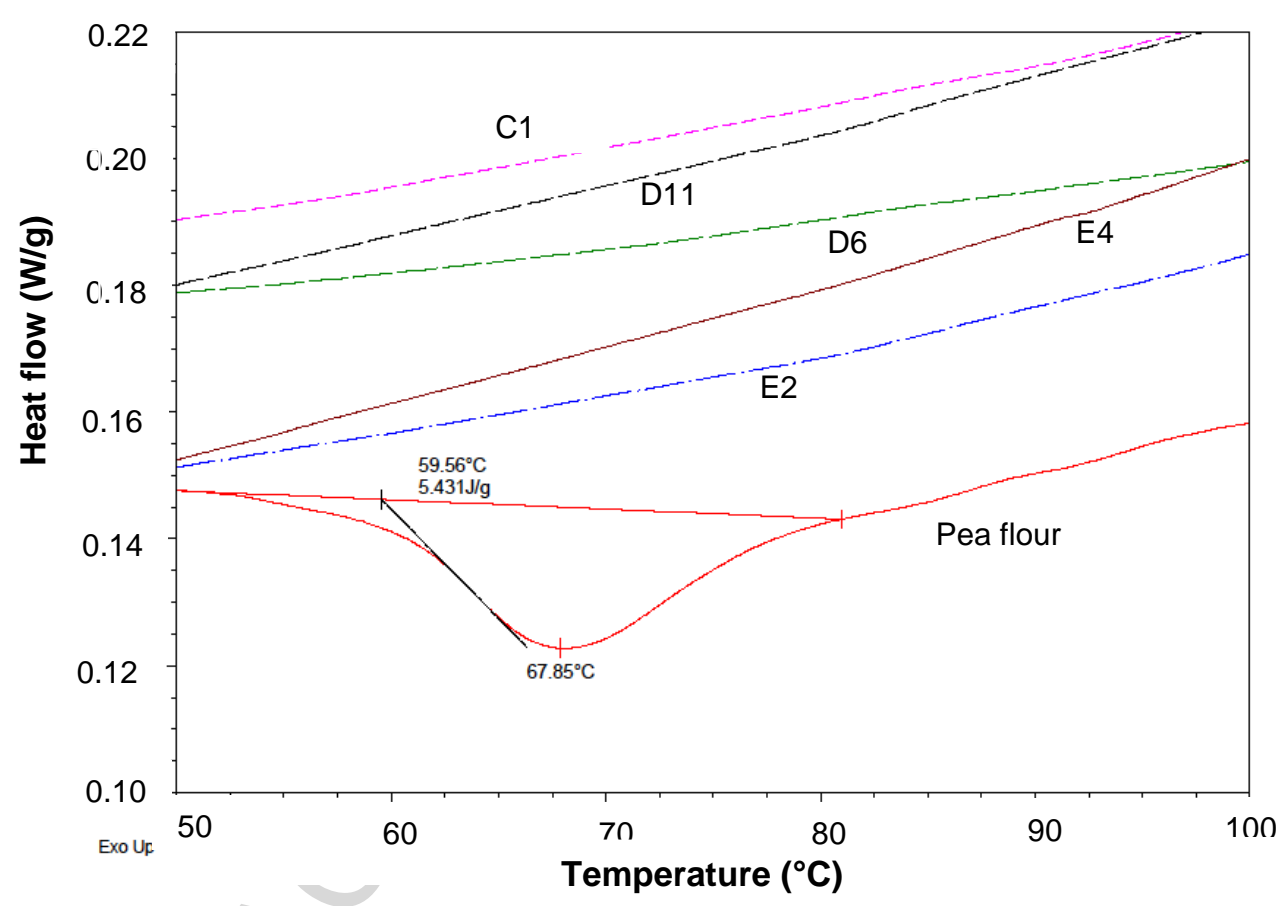

Fig. 5. 


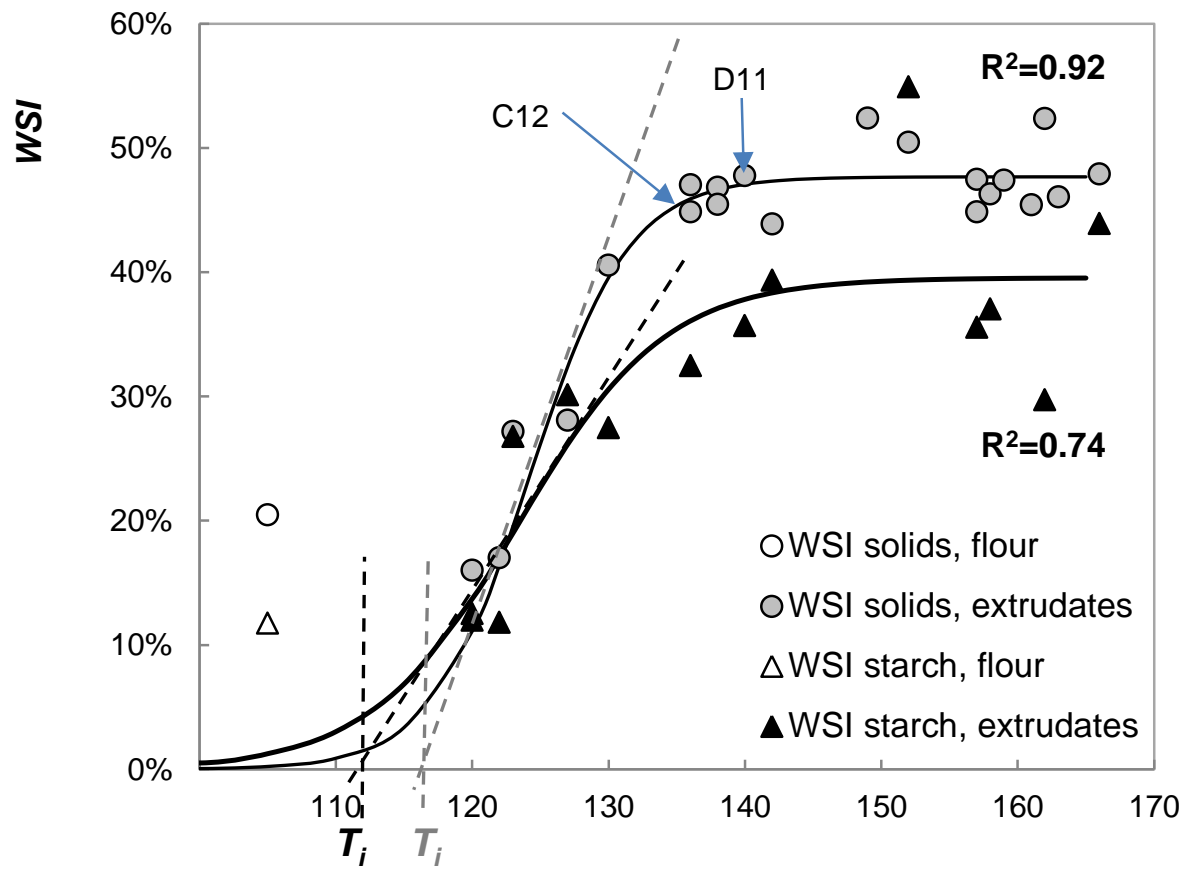

Product temperature $T\left({ }^{\circ} \mathrm{C}\right)$

Fig. 6. 
(a)

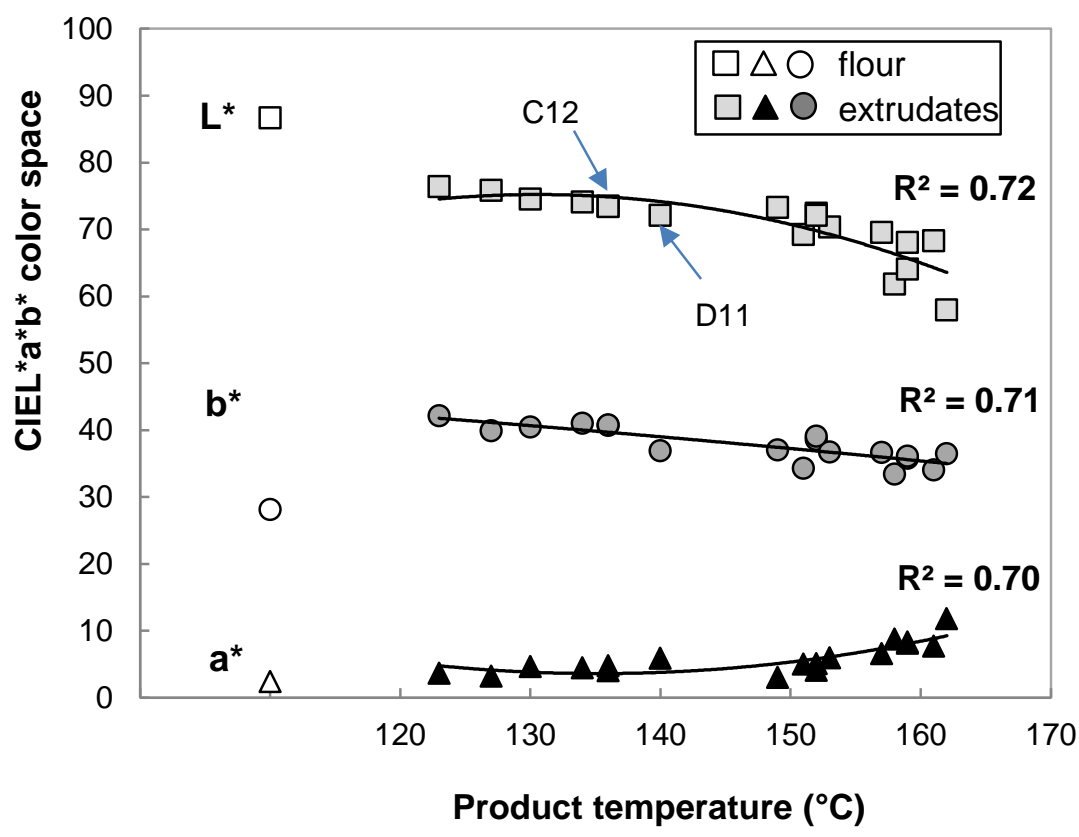

(b)

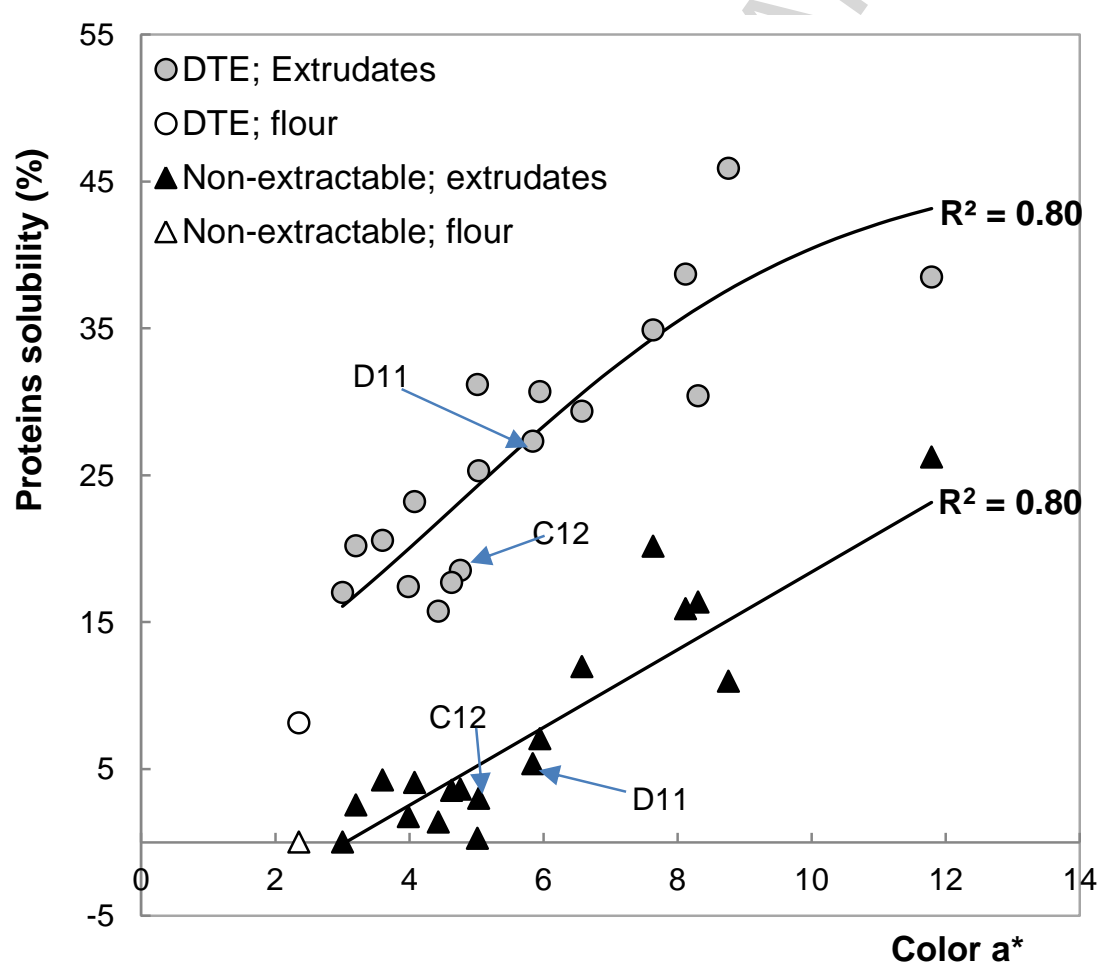

Fig. 7. 
(a)

Sample C12 $\left(M C 21 \%, 136^{\circ} \mathrm{C}, \mathbf{5 4 9} \mathbf{~ k J / k g}\right)$

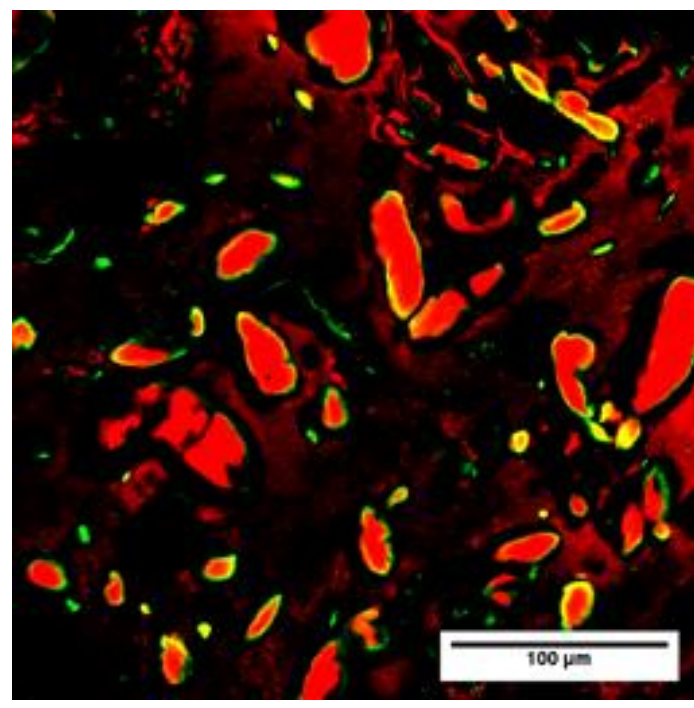

(b)

Sample D11 $\left(M C 19 \%, 140^{\circ} \mathrm{C}, 722 \mathbf{~ k J} / \mathbf{k g}\right)$

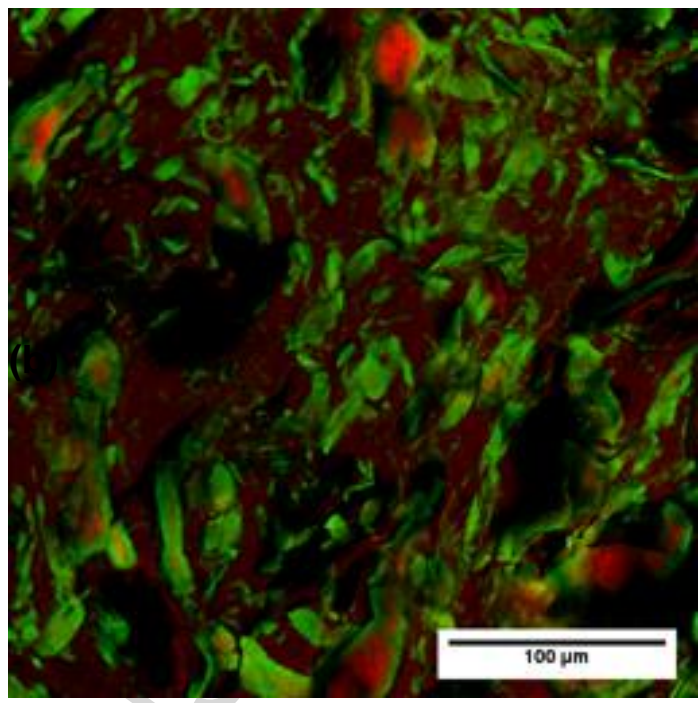

Fig. 8. 
Table 1. Summary of extrusion parameters and variables

\begin{tabular}{|c|c|c|c|c|c|c|c|c|}
\hline \multicolumn{9}{|c|}{ Expanded samples } \\
\hline \multicolumn{9}{|c|}{ Extruder configuration $\mathrm{A}$ and die configuration $\mathrm{C}$} \\
\hline & \multicolumn{5}{|c|}{ Operating conditions } & \multicolumn{3}{|c|}{ Measured variables } \\
\hline Trial & $\begin{array}{c}M C \\
\text { \%w.b. }\end{array}$ & $\begin{array}{c}Q_{F} \\
(\mathrm{~kg} / \mathrm{h})\end{array}$ & $\begin{array}{c}Q_{W} \\
(\mathrm{~kg} / \mathrm{h})\end{array}$ & $\begin{array}{c}N \\
(\mathrm{rpm})\end{array}$ & $\begin{array}{l}T_{\text {die }} \\
\left({ }^{\circ} \mathrm{C}\right)\end{array}$ & $\begin{array}{c}T \\
\left({ }^{\circ} \mathrm{C}\right)\end{array}$ & $\begin{array}{c}S M E \\
(\mathrm{~kJ} / \mathrm{kg})\end{array}$ & $\begin{array}{c}\text { Die pressure } \\
\text { (bar) }\end{array}$ \\
\hline $\mathrm{C} 1$ & 21 & 10 & 1.13 & 700 & 150 & $162^{\mathrm{a}}$ & $1156^{\mathrm{a}}$ & $47^{\mathrm{h}}$ \\
\hline $\mathrm{C} 2$ & 21 & 10 & 1.13 & 500 & 150 & $158^{\mathrm{b}}$ & $1002^{b}$ & $58^{\mathrm{gh}}$ \\
\hline $\mathrm{C} 3$ & 21 & 10 & 1.13 & 300 & 150 & $139^{\mathrm{de}}$ & $754^{\mathrm{ce}}$ & $84^{\mathrm{e}}$ \\
\hline $\mathrm{C} 4$ & 21 & 20 & 2.26 & 700 & 150 & $159^{\mathrm{ab}}$ & $830^{c}$ & $83^{\mathrm{e}}$ \\
\hline C5 & 21 & 20 & 2.26 & 500 & 150 & $151^{\mathrm{c}}$ & $698^{\text {def }}$ & $102^{\mathrm{d}}$ \\
\hline C6 & 21 & 20 & 2.26 & 300 & 150 & $134^{\mathrm{f}}$ & $549^{g}$ & $134^{\mathrm{b}}$ \\
\hline C7 & 26 & 20 & 3.53 & 300 & 150 & $127^{\mathrm{g}}$ & $448^{\mathrm{h}}$ & $100^{\mathrm{d}}$ \\
\hline $\mathrm{C} 8$ & 26 & 20 & 3.53 & 500 & 150 & $142^{\mathrm{d}}$ & $627^{\mathrm{f}}$ & $78^{\mathrm{ef}}$ \\
\hline C9 & 26 & 20 & 3.53 & 700 & 150 & $152^{\mathrm{c}}$ & $690^{\mathrm{ef}}$ & $70^{\mathrm{fg}}$ \\
\hline $\mathrm{C} 10$ & 21 & 20 & 2.27 & 700 & 130 & $161^{\mathrm{ab}}$ & $955^{\mathrm{b}}$ & $121^{\mathrm{c}}$ \\
\hline C11 & 21 & 20 & 2.27 & 500 & 130 & $153^{\mathrm{c}}$ & $770^{\mathrm{cd}}$ & $133^{\mathrm{bc}}$ \\
\hline $\mathrm{C} 12$ & 21 & 20 & 2.27 & 300 & 130 & $136^{\mathrm{ef}}$ & $549^{\mathrm{g}}$ & $179^{\mathrm{a}}$ \\
\hline \multicolumn{9}{|c|}{ Extruder configuration $\mathrm{A}$ and die configuration $\mathrm{D}$} \\
\hline & \multicolumn{5}{|c|}{ Operating conditions } & \multicolumn{3}{|c|}{ Measured variables } \\
\hline D1 & 21 & 10 & 1.12 & 700 & - & $157^{\mathrm{a}}$ & $1107^{\mathrm{a}}$ & $42^{\mathrm{h}}$ \\
\hline D2 & 21 & 10 & 1.12 & 500 & - & $152^{\mathrm{b}}$ & $967^{\mathrm{b}}$ & $46^{\mathrm{gh}}$ \\
\hline D3 & 21 & 10 & 1.12 & 300 & - & $136^{\mathrm{e}}$ & $754^{d}$ & $76^{\mathrm{ce}}$ \\
\hline D4 & 26 & 20 & 3.56 & 700 & - & $148^{\mathrm{c}}$ & $618^{\mathrm{fg}}$ & $43^{\mathrm{gh}}$ \\
\hline D5 & 26 & 20 & 3.56 & 500 & - & $138^{\mathrm{de}}$ & $524^{\mathrm{h}}$ & $63^{\text {ef }}$ \\
\hline D6 & 26 & 20 & 3.56 & 300 & - & $123^{\mathrm{g}}$ & $427^{\mathrm{i}}$ & $80^{\mathrm{cd}}$ \\
\hline D7 & 21 & 20 & 2.26 & 300 & - & $132^{\mathrm{f}}$ & $549^{\mathrm{gh}}$ & $106^{\mathrm{b}}$ \\
\hline D8 & 21 & 20 & 2.26 & 500 & - & $149^{b c}$ & $663^{\text {ef }}$ & $68^{\text {def }}$ \\
\hline D9 & 21 & 20 & 2.26 & 700 & - & $160^{\mathrm{a}}$ & $779^{\mathrm{d}}$ & $58^{\mathrm{fg}}$ \\
\hline D10 & 19 & 20 & 1.56 & 700 & - & $159^{\mathrm{a}}$ & $883^{c}$ & $63^{\mathrm{ef}}$ \\
\hline D11 & 19 & 20 & 1.56 & 500 & - & $140^{\mathrm{d}}$ & $721^{\mathrm{de}}$ & $86^{c}$ \\
\hline D12 & 19 & 20 & 1.56 & 300 & - & $130^{\mathrm{f}}$ & $567^{\mathrm{gh}}$ & $124^{\mathrm{a}}$ \\
\hline \multicolumn{9}{|c|}{$\begin{array}{c}\text { Dense samples } \\
\end{array}$} \\
\hline \multicolumn{9}{|c|}{ Extruder configuration $\mathrm{B}$ and die configuration $\mathrm{D}$} \\
\hline & \multicolumn{5}{|c|}{ Operating conditions } & \multicolumn{3}{|c|}{ Measured variables } \\
\hline E1 & 31 & 20 & 6 & 350 & 130 & $122^{b}$ & $39^{\mathrm{b}}$ & $5^{a}$ \\
\hline E2 & 35 & 20 & 8 & 300 & 120 & $115^{\mathrm{c}}$ & $47^{\mathrm{ab}}$ & $10^{\mathrm{a}}$ \\
\hline E3 & 28 & 20 & 5 & 300 & 135 & $129^{\mathrm{a}}$ & $53^{\mathrm{a}}$ & $5^{\mathrm{a}}$ \\
\hline $\mathrm{E} 4$ & 26 & 20 & 4 & 300 & 135 & $129^{\mathrm{a}}$ & $55^{\mathrm{a}}$ & $5^{\mathrm{a}}$ \\
\hline
\end{tabular}

The comparison was done between means of measured variables of samples made from same configuration of extruder and die. The reported values are the mean of three determinations. The values followed by a different superscript in each column are significantly different $(\mathrm{p}<0.05)$.

$Q_{F}=$ mass flow rate of pea flour

$Q_{W}=$ mass flow rate of water 
$N=$ screw speed

$T_{d i e}=$ imposed die temperature

$T=$ product temperature

$M C=$ moisture content

$S M E=$ specific mechanical energy

Table 2. Physico-chemical characteristics of some extruded samples

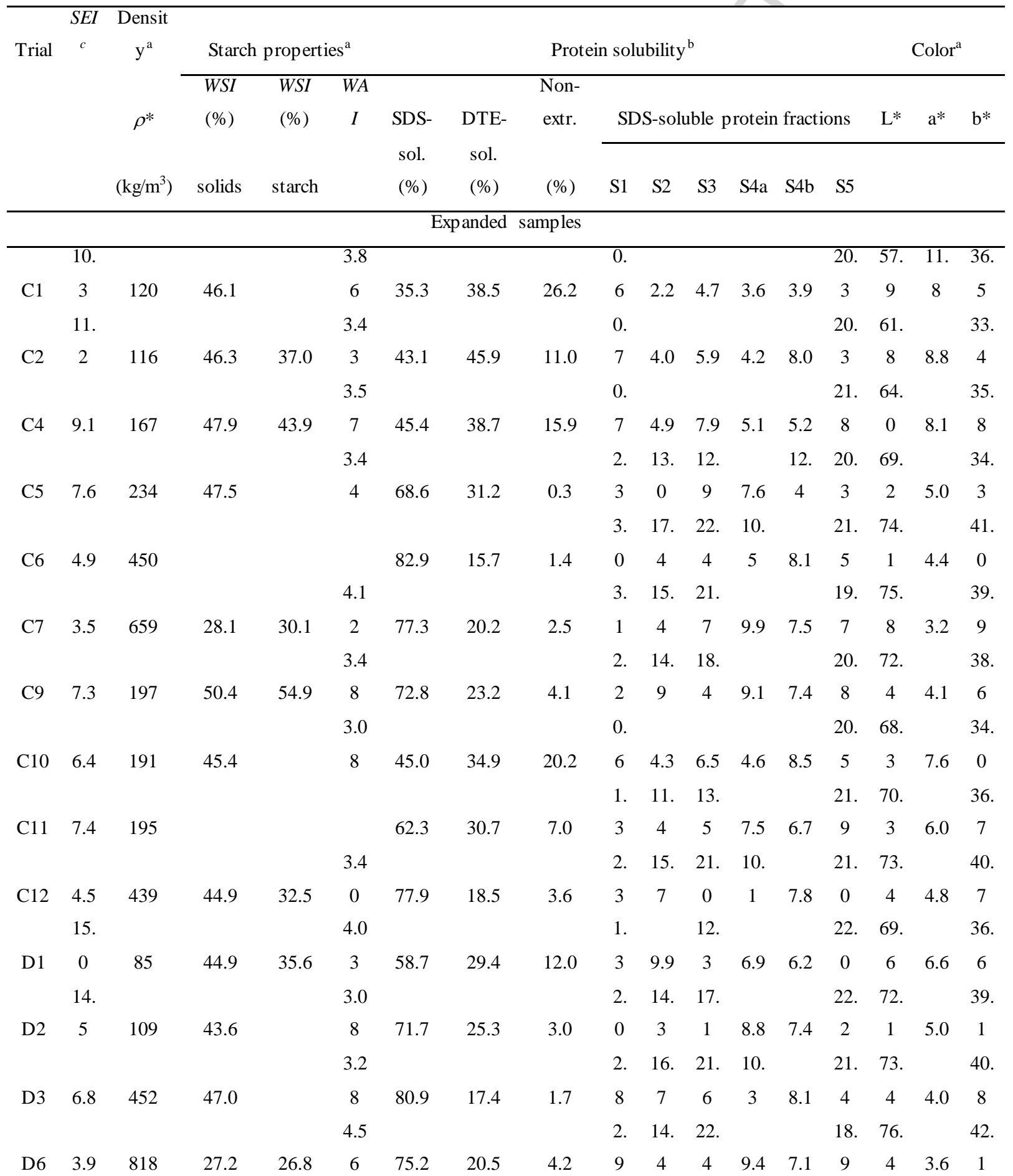




\begin{tabular}{|c|c|c|c|c|c|c|c|c|c|c|c|c|c|c|c|c|c|}
\hline \multirow[b]{2}{*}{ D8 } & & & & & 2.9 & & & & 3. & 16. & 18. & 10. & 14. & 19. & 73. & & 37. \\
\hline & 9.8 & 200 & 52.4 & & 6 & 83.0 & 17.0 & 0 & 8 & 6 & 7 & 1 & 8 & 1 & 2 & 3.0 & 0 \\
\hline \multirow{3}{*}{ D10 } & 14. & & & & 3.6 & & & & 1. & & 10. & & & 21. & 68. & & 36. \\
\hline & 2 & 106 & 47.4 & & 1 & 53.3 & 30.4 & 16.4 & 0 & 8.0 & 4 & 6.1 & 5.8 & 8 & 0 & 8.3 & 1 \\
\hline & 15. & & & & 3.4 & & & & 1. & 13. & 15. & & & 22. & 72. & & 36. \\
\hline \multirow[t]{2}{*}{ D11 } & 5 & 103 & 47.8 & 35.7 & 7 & 67.4 & 27.3 & 5.3 & 5 & 2 & 1 & 8.1 & 7.1 & 4 & 1 & 5.8 & 9 \\
\hline & & & & & 4.0 & & & & 2. & 15. & 21. & 10. & & 21. & 74. & & 40. \\
\hline D12 & 7.0 & 321 & 40.6 & 27.5 & 9 & 78.8 & 17.7 & 3.5 & 4 & 9 & 0 & 2 & 8.0 & 4 & 5 & 4.6 & 5 \\
\hline \multicolumn{18}{|c|}{ Dense samples } \\
\hline & 2.8 & & & & 4.7 & & & & 2. & 18. & 27. & 12. & 9.9 & 25. & & & \\
\hline \multirow[t]{2}{*}{ E1 } & 4 & 877 & 17 & 11.8 & 4 & 95.4 & 4.60 & 0 & 5 & 4 & 1 & 5 & 4 & 0 & & & \\
\hline & 1.8 & & & & 4.9 & & & & 1. & 16. & 29. & 11. & 10. & 26. & & & \\
\hline \multirow[t]{2}{*}{ E2 } & 9 & 930 & 16 & 12.0 & 5 & 95.6 & 4.46 & 0 & 7 & 4 & 7 & 3 & 4 & 1 & & & \\
\hline & 2.7 & & & & & & & & 2. & 17. & 28. & 10. & 10. & 25. & & & \\
\hline \multirow[t]{2}{*}{ E3 } & 1 & 917 & & 12.5 & & 95.1 & 4.93 & 0 & 4 & 6 & 9 & 9 & 1 & 2 & & & \\
\hline & 2.1 & & & & 3.0 & & & & 2. & 17. & 29. & 10. & 9.9 & 24. & & & \\
\hline $\mathrm{E} 4$ & 2 & 1058 & 19 & 12.0 & 8 & 95.0 & 5.02 & 0 & 6 & 7 & 2 & 8 & 9 & 8 & & & \\
\hline Flou & & & & & & & & & 1. & & 32. & 13. & 17. & 20. & 86. & & 28. \\
\hline$r$ & & & 20.5 & 11.7 & 2.3 & 91.9 & 8.1 & 0 & 2 & 6.8 & 3 & 7 & 7 & 2 & 7 & 2.4 & 1 \\
\hline
\end{tabular}

sol. $=$ soluble

Non-extr. $=$ non-extractable

The reported values are the average of several repetitions

${ }^{a}$ Three repetitions

${ }^{\mathrm{b}}$ Two repetitions

${ }^{\mathrm{c}}$ Thirty-five repetitions

Table 3. Insignificant effect of extrusion variables on protein solubility (one-way ANOVA, $<<0.05$ )

\begin{tabular}{llll}
\hline & Factor & $F$-value & Critical $F$-value \\
\hline \multicolumn{1}{c}{ SDS-soluble protein fraction (\%) } & Temperature & & \\
\multicolumn{1}{c}{ S5 } & & $2.825^{*}$ & 3.682 \\
SDS-soluble proteins (\%) & Moisture content & $0.394^{*}$ & 3.682 \\
DTE-soluble proteins (\%) & & $0.750^{*}$ & 3.682 \\
Non-extractable proteins (\%) & & $0.873^{*}$ & 3.682 \\
\hline SDS-soluble proteins (\%) & Die geometry & $0.490^{*}$ & 3.682 \\
DTE-soluble proteins (\%) & & $2.053^{*}$ & 4.494 \\
Non-extractable proteins $(\%)$ & & $2.774^{*}$ & 4.494 \\
\hline
\end{tabular}

* Insignificant : $F<$ Critical $F$ 


\section{APPENDIX}

\section{Melting temperature of pea flour}

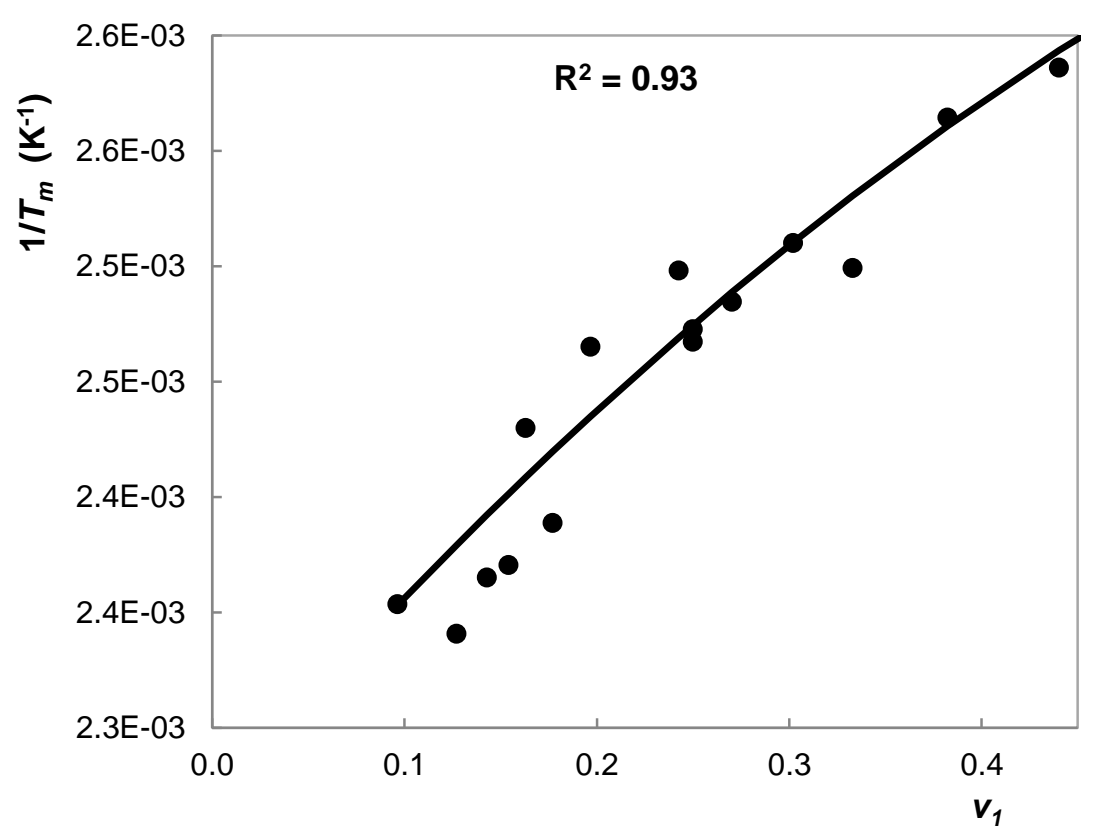

Fig. A1. Change of melting temperature $\left(T_{m}\right)$ with the water volume fraction $v_{l}$. The points refer to melting temperature obtained by DSC. The solid lines refer to the best fit using Flory-Huggins equation (Eq. A1)

The variations of melting temperature $\left(T_{m}\right.$, in $\left.\mathrm{K}\right)$ of pea flour with water volume fraction can be fitted by Flory-Huggins equation $\left(\mathrm{R}^{2}=0.93\right)$.

$\left(\frac{1}{T_{m}}-\frac{1}{T_{m}^{\circ}}\right)=\frac{R}{\Delta H_{u}} \frac{V_{u}}{V_{1}}\left(v_{1}-\chi_{1} v_{1}^{2}\right)$

where $T_{m}^{\circ}$ is the melting temperature of anhydrous starch (in $\mathrm{K}$ ), $R$ is the gas constant $(8.31 \mathrm{~J} / \mathrm{mol} . \mathrm{K}$ ), $\Delta H_{u}$ is the melting enthalpy per mole of monomer unit (or anhydroglucose) (in $\mathrm{J} / \mathrm{mol}$ ), $V_{u} / V_{l}$ is the ratio of molar volume of the monomer unit to the molar volume of water (dimensionless), and $\chi_{1}$ is the 
Flory-Huggins starch-water interaction parameter (dimensionless). $v_{1}$ was obtained under the assumption that the density of anhydrous flour is the same as anhydrous starch, $1500 \mathrm{~kg} / \mathrm{m}^{3}$ (Della Valle \& Vergnes, 1994) ${ }^{1}$. Fitting the experimental data on $T_{m}$ and $v_{1}$ by Eq. A1, see Fig. A1, we obtained the following results: $T_{m}^{\circ}=168.4{ }^{\circ} \mathrm{C}, \Delta H_{u}=56.49 \mathrm{~kJ} / \mathrm{mol}, \chi_{1}=0.4999$. The computed values of melting temperature and melting enthalpy of anhydrous pea flour were in accordance with those reported in literature for starches (Colonna \& Buléon, 1994) ${ }^{2}$.

\section{Fitting parameters}

Table A1. Fitting of measured extrudate properties

\begin{tabular}{|c|c|c|c|c|c|c|}
\hline Fig & Data series & Equation & \multicolumn{4}{|c|}{ Parameters } \\
\hline \multirow[t]{2}{*}{ Fig. 1a } & & $T=m \times S M E+b$ & $m$ & \multicolumn{2}{|l|}{$b$} & $\mathrm{R}^{2}$ \\
\hline & & & 0.039 & 118 & & 0.74 \\
\hline \multirow[t]{2}{*}{ Fig. 1b } & & $S M E=b_{1}(Q / N)^{b 2}$ & $b_{1}$ & \multicolumn{2}{|l|}{$b_{2}$} & $\overline{\mathrm{R}^{2}}$ \\
\hline & & & 1472 & -0.53 & & 0.86 \\
\hline \multirow[t]{2}{*}{ Fig. $2 \mathrm{a}$} & & \multirow[t]{2}{*}{$\rho^{*}=a /\left(1+\exp \left(-k \times\left(T-T_{c}\right)\right)\right)$} & $a$ & $T_{c}$ & $k$ & $\mathrm{R}^{2}$ \\
\hline & & & 1414 & 127 & -0.078 & 0.77 \\
\hline \multirow[t]{2}{*}{ Fig. $2 b$} & & $S E I=b_{1} \times \rho^{* b 2}$ & $b_{1}$ & \multicolumn{2}{|l|}{$b_{2}$} & $\mathrm{R}^{2}$ \\
\hline & & & 370 & \multicolumn{2}{|l|}{-0.71} & 0.91 \\
\hline \multirow[t]{4}{*}{ Fig. $4 a$} & & Sol. $=a /\left(1+\exp \left(-k \times\left(T-T_{c}\right)\right)\right)$ & $a$ & $T_{c}$ & $k$ & $\mathrm{R}^{2}$ \\
\hline & \multicolumn{2}{|l|}{ SDS-soluble proteins (\%) } & 86.8 & 162 & -0.13 & 0.83 \\
\hline & \multicolumn{2}{|l|}{ DTE-soluble proteins (\%) } & 102 & 175 & 0.04 & 0.75 \\
\hline & \multicolumn{2}{|l|}{ Non-extractable proteins (\%) } & 27.9 & 159 & 0.29 & 0.81 \\
\hline Fig. $4 b$ & & Sol. $=a /\left(1+\exp \left(-k \times\left(T-T_{c}\right)\right)\right)$ & $a$ & $T_{c}$ & $k$ & $\mathrm{R}^{2}$ \\
\hline
\end{tabular}

${ }^{1}$ Della Valle, G., \& Vergnes, B. (1994). Propriétés thermophysiques et rhéologiques des substrats utilisés en cuisson-extrusion. In P. Colonna \& G. Della Valle (Eds.), La cuisson-extrusion (pp. 440-467). Paris: Lavoisier Tec \& Doc.

${ }^{2}$ Colonna, P., \& Buléon, A. (1994). Transformations structurales d'amidons. In P. Colonna \& G. Della Valle (Eds.), La cuisson-extrusion (pp. 18-43). Paris: Lavoisier Tec \& Doc. 
S1

S2

S3

S4a

S4b

S5
2.56

16.3

26.5

10.6

Sol. $=m \times T+b$

m

$-0.083$

19.4

0.58

$-0.084 \quad 34.2$

0.50

a $\quad T_{c}$

$T_{c}$

0.48

124

0.40

123

0.19

0.74

\begin{tabular}{|c|c|c|c|c|c|c|}
\hline \multicolumn{2}{|l|}{ Fig. 7} & $L^{*}, a^{*}, b^{*}=a /\left(1+\exp \left(-k \times\left(T-T_{c}\right)\right)\right)$ & $a$ & $T_{c}$ & $k$ & $\overline{\mathrm{R}^{2}}$ \\
\hline \multicolumn{2}{|r|}{$\mathrm{L}^{*}$} & & 74.7 & 173 & -0.14 & 0.72 \\
\hline \multicolumn{3}{|c|}{$a^{*}$} & 23503 & 431 & 0.03 & 0.71 \\
\hline \multicolumn{3}{|c|}{$\mathrm{b}^{*}$} & 55.9 & 198 & -0.0146 & 0.70 \\
\hline \multirow[t]{4}{*}{ Fig. $7 \mathrm{~b}$} & DTE-soluble proteins (\%) & Sol. DTE $=a /\left(1+\exp \left(-k \times\left(T-T_{c}\right)\right)\right)$ & $a$ & $\bar{T} T_{c}$ & $k$ & $\mathrm{R}^{2}$ \\
\hline & \multirow{3}{*}{ Non-extractable proteins (\%) } & & 46.6 & 4.79 & 0.36 & 0.80 \\
\hline & & Non-extract. $=m \times a^{*}+b$ & $m$ & $\bar{b}$ & & $\mathrm{R}^{2}$ \\
\hline & & & 2.64 & -8.05 & & 0.80 \\
\hline
\end{tabular}

\section{Computing the onset temperature $\left(T_{\mathrm{i}}\right)$ using a sigmoidal function : $y=\mathrm{f}(T)$}

Sigmoidal function is defined

$$
y=\frac{a}{1+\exp \left(-k\left(T-T_{c}\right)\right)}
$$


where $a$ is the amplitude of the curve, $k$ contributes to the slope of the tangent passing through the inflection point at $T_{c}$.

The function has value $y_{0}$ for $T=0$ :

$$
y_{0}=a\left(1+\exp k T_{c}\right)
$$

For $T \rightarrow \infty$ values $y_{\infty}$ are $a$ and 0 for $k$ positive and negative, respectively.

For $T \rightarrow-\infty$ values $y_{-\infty}$ are 0 and $a$ for $k$ positive and negative, respectively.

The derivative of the sigmoid function is

$$
\frac{d y}{d T}=\frac{a k \exp \left(-k\left(T-T_{c}\right)\right)}{\left[1+\exp \left(-k\left(T-T_{c}\right)\right]^{2}\right.}
$$

The tangent at inflection point $\left(T_{c}, a / 2\right)$ has value:

$$
\left.\frac{d y}{d T}\right|_{T_{c}}=\frac{a k}{4}
$$

The intersection of the tangent at the inflection point with the line parallel with the axis $T$ at a distance of $y_{-\infty}$ stands for the temperature of the solubility change onset $T_{\mathrm{i}}$ :

$$
T_{i}=\frac{2}{a k}\left(2 y_{0}-a\right)+T_{c}
$$




\section{Graphical abstract}

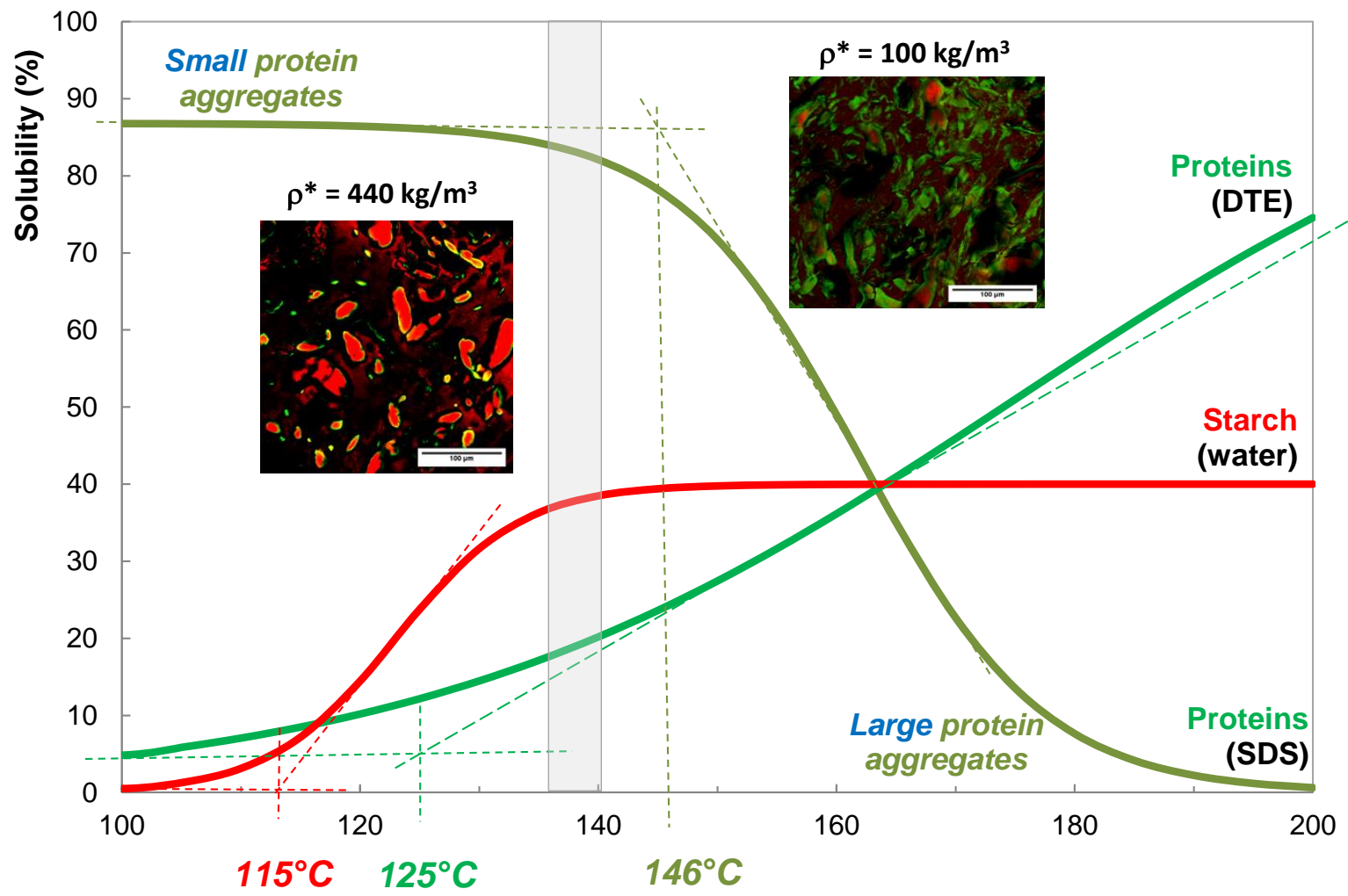

Melt temperature $\left({ }^{\circ} \mathrm{C}\right)$

\section{From protein aggregation and starch melting to expansion at die outlet} via the composite morphology of extruded foam cell-walls

The design of high-protein expanded foods is still a challenge, likely due to the reactivity of protein components under thermomechanical treatment and its effect on extrudate structure and texture. Material temperature governs concomitant starch and protein changes during pea flour extrusion. Protein insolubilization, mainly due to $\mathrm{S}-\mathrm{S}$ bonds, is triggered at $\mathrm{T} \approx 125^{\circ} \mathrm{C}$, and contributes to expansion by morphology changes. CSLM micrographs of two samples extruded under similar conditions show different expansion (density $\rho^{*}$ ) and morphology of amorphous starch/protein aggregates. These differences are probably due to slight variations in specific mechanical energy $(S M E)$, moisture content $(M C)$ or strain at the die. 


\section{Highlights}

- Extrusion temperature, via dissipated energy, governs starch and protein changes

- Protein changes lead to various amorphous starch-aggregated proteins morphologies

- Morphology of starch-protein blend affects expansion through rheological properties

- Onset temperature for biopolymers changes was determined from models 